\title{
Retrospective voting and the polarisation of available alternatives
}

Canadian Journal of Political Science, accepted

(C) Canadian Journal of Political Science

\begin{abstract}
Government cohesiveness is known to moderate retrospective voting. While previous work on this topic has focused on characteristics of the government, we build on the literature on clarity of responsibility and the literature on valence to argue that the extent to which government and opposition are ideologically distinct moderates retrospective voting as well. Two alternative expectations follow from these two theoretical perspectives. While the clarity of responsibility framework leads to the expectation that a larger difference between government and opposition will strengthen retrospective voting, the valence literature presumes that retrospective voting is stronger when ideological differences are small. Using the data of the Comparative Study of Electoral Systems (CSES) project, we find evidence that is in line with the clarity of responsibility framework: the higher the degree of ideological polarisation between government and opposition, the larger the effect of retrospective performance evaluations on the vote.
\end{abstract}

Keywords: Retrospective voting, clarity of responsibility, polarisation, incumbency voting 
According to theories of retrospective voting, voters evaluate the past government's performance and make their vote choice accordingly. While satisfied voters support the incumbent, those who are dissatisfied with the government's performance are more likely to support an opposition party (Key, 1966; Lewis-Beck and Stegmaier, 2000). Retrospective voting is not only one of the most investigated topics in voting behaviour research (Fiorina, 1981; Healy and Malhotra, 2013), it is also a key concept in normative work on the functioning of representative democracy. That is, by voting retrospectively, voters can hold incumbents accountable - ensuring citizen control on how representatives act while in office (Przeworski, Stokes, and Manin, 1999).

Given that it is normatively desirable that citizens vote retrospectively and hold the government to account, researchers have voiced concern about the apparent instability of mechanisms of retrospective voting (Anderson, 2007), leading to a stream of publications on the conditions that allow for reward and punishment (Duch and Stevenson, 2008; Silva and Whitten, 2017). These studies have focused mostly on identifying formal institutional rules that make it more or less easy for voters to attribute responsibility for the country's state of affairs (Nadeau, Niemi, and Yoshinaka, 2002; Powell and Whitten, 1993; Schwindt-Bayer and Tavits, 2016; Whitten and Palmer, 1999). In a recent contribution to this vast literature, Hobolt, Tilley, and Banducci (2013) break with the traditional approach of focusing on static institutional factors by distinguishing a static and a more dynamic dimension. They find the latter to be a more important factor for explaining contextual variation in retrospective voting. We build on their work and study how characteristics of who is in power moderate retrospective voting and draw attention to the role of the opposition - and how different it is from the government. In doing so, we take into account the fact that the alternative options that voters have matter in their decision whether or not to punish the incumbent (Anderson, 2000).

Our focus is on how ideologically different - i.e., polarized - government and opposition are. We derive two contrasting expectations. On the one hand, if the government and the opposition are more ideologically distinct, this will make it easier for voters to distinguish both. Furthermore, if incumbent and opposition parties have a distinct ideological position and adhere to different policies, a higher degree of polarisation implies that a vote for an opposition party ensures different policies to be pursued in the future (Hellwig, 2010). 
Following the literature on clarity, this might strengthen retrospective voting because voters can recognize more clearly which party/-ies they should reward or punish for the government's track record (Powell and Whitten, 1993; Silva and Whitten, 2017). On the other

hand, work on valence issues has argued that when parties are ideologically close, voters cannot distinguish between parties in spatial terms, leading them to take into account valence attributes instead (Green and Hobolt, 2008). Hence, the valence literature leads to the expectation that retrospective voting will be weaker when government and opposition are more ideologically distant.

For investigating whether and how the polarisation between government and opposition moderates retrospective voting, we make use of the data of the second and third module of the Comparative Study of Electoral Systems (CSES) project, covering 52 elections in 30 countries. We study the moderating effect of the ideological distinctness of government and opposition, by means of a novel measure of what we call the 'polarisation of alternatives'. The results show a strong positive moderation effect: the more ideologically distinct the government and the opposition are, the larger the impact of retrospective performance evaluations on the vote. Our findings suggest that ideologically distinct alternatives make it easier for the voter to vote according to her evaluation of the government's performance, which is in line with the clarity of responsibility literature.

\section{Theoretical background: Retrospective voting in a comparative perspective}

Retrospective voting theory argues that the vote choice is influenced by the performance of the incumbent party/-ies. It stipulates that voters retrospectively evaluate the government's performance, and that these evaluations subsequently influence their party choice (Key, 1966; Lewis-Beck and Stegmaier, 2000; Strøm, 2000). A wealth of literature shows empirically that those who are satisfied are more likely to support the incumbent, while the dissatisfied are more likely to support an opposition party (Duch and Stevenson, 2008; Fiorina, 1981; Healy and Malhotra, 2013). Citizens' evaluations of government performance can relate to different issues. Many scholars study the impact of citizens' evaluations of the state of the economy (Nannestad and Paldam, 1994), but others have shown that perceptions of corruption (Ecker, Glinitzer, and Meyer, 2016), war casualties (Karol and Miguel, 2007), or natural disaster 
management (Gasper and Reeves, 2011) as well influence support for the incumbent party. Moving away from performance evaluations that relate to a specific domain or policy issues, others have shown that evaluations of the government's performance "in general" are strong predictors of the vote choice as well (de Vries and Giger, 2014; Stiers, forthcoming).

Overall, there is strong evidence that retrospective performance evaluations affect voters' choices, but there is substantial heterogeneity in their effect. At an individual level, factors such as citizens' level of political knowledge or their partisanship moderate the impact of performance evaluations. Voters with higher levels of knowledge appear to hold governments accountable to a larger extent (de Vries and Giger, 2014; Duch, 2001), while partisanship biases perceptions of how the government performs (Tilley and Hobolt, 2011).

Most work on heterogeneity in the effect of retrospective evaluations, however, has focused on differences between countries (Duch and Stevenson, 2008). Notably, the literature on clarity of responsibility has shown that complex institutional rules blur the lines of responsibility and decrease the impact of performance evaluations on the vote (Silva and Whitten, 2017). In their seminal study on the topic, Powell and Whitten (1993) argue that institutional political rules moderate the impact of economic performance on the vote. They state that ' $[\mathrm{t}]$ he greater the perceived unified control of policymaking by the incumbent government, the more likely is the citizen to assign responsibility for economic and political outcomes to the incumbents' (Powell and Whitten, 1993: 398). Testing their expectations empirically, they find support for their expectations, as they find evidence of economic voting in "high clarity" settings, but not in "low clarity" contexts.

Inspired by the work of Powell and Whitten (1993), many others have studied how institutional factors, such as the electoral and the political system or whether government is unitary or federal, moderate the attribution of responsibility and the impact of incumbents' performance on electoral results (Bengtsson, 2004; Nadeau et al., 2002; Whitten and Palmer, 1999). Reviewing earlier work on clarity of responsibility and its impact, Hobolt et al. (2013) have argued for the need to distinguish between two dimensions of clarity; institutional clarity and government clarity. Describing these two dimensions of clarity, Hobolt et al. (2013: 169170) indicate: 
The institutional clarity dimension is about the institutional concentration of power. This captures the formal division of powers both horizontally between the executive and the legislature, and vertically between different levels of government. (...) By contrast to the institutional clarity dimension, the government clarity dimension is not directly concerned with formal institutional rules, but rather the 'cohesiveness' of the incumbent government at a particular time.

Testing the impact of institutional and government clarity empirically, Hobolt et al. (2013) find that it is the latter that matters most. Hence, their results indicate that government clarity, which is the more dynamic of both dimensions, better captures contextual variation in retrospective voting. In this paper, we build on their work and argue that another possibly important - and dynamic - moderator of retrospective voting should be taken into account: whether or not voters dispose of a valid alternative to the governing parties.

In fact, the role of available alternatives has received remarkably little attention in work on retrospective voting. In one of the few studies on this topic, Anderson (2000) analyses whether economic voting is moderated by what he calls the "clarity of available alternatives". He argues that voters are more likely to punish the incumbent government if there is a clear and viable alternative to the government available. If there are many parties running in the election, he explains, it is less clear which opposition party might throw the governing party out of office and take over incumbent control. If there are few alternative parties, however, it is more likely that there is a clear alternative - i.e., that voting for the main opposition party makes for a high probability of replacing the current incumbent. Hence, he argues: 'A more clearly defined set of viable alternatives to the incumbent government should lead citizens to more readily express content or discontent with the ruling party or parties' (Anderson, 2000: 156).

Using the effective number of parliamentary parties as a measure of the clarity of available alternatives, Anderson (2000) finds that a larger set of available alternatives attenuates the effect of economic perceptions on the vote. Furthermore, he also finds a direct effect: the higher the effective number of parliamentary parties, the higher the support for the incumbent government, ceteris paribus. 
Second, Bengtsson (2004: 756) - who builds on the work of Anderson (2000) - states that 'a greater number of effective parties is assumed to make it more difficult for voters to estimate what an alternative government would look like, since more parties are competing for power.' Using aggregate-level data in a sample of elections in Western democracies, she finds support for the hypothesis that economic effects are stronger when there are only a few viable alternatives to support. This finding is in line with the results reported by Hellwig (2010: 162), as he argues and finds that voters are better able to link their retrospective performance evaluations to their vote when administrative power is concentrated in the hands of fewer actors.

Previous studies thus have argued that the presence of alternatives to the government conditions retrospective voting. Both Anderson (2000) and Bengtsson (2004) have tested this argument by means of an indicator of the effective number of parties. For characterising the available alternatives the voter can choose from and its impact on retrospective voting, however, we argue that it is important to take into account how different those alternatives are. We focus on the ideological distinctiveness of incumbent and opposition parties, which, as we argue, affects whether or not the opposition parties can be clearly distinguished from the incumbent parties. In doing so, we take into account insights from the party systems literature, that have argued that the 'quality of party competition' (i.e., its polarization) is often a more important factor than the quantity of parties (Dalton, 2008). 
Dieter Stiers \& Ruth Dassonneville

\section{Expectations}

\section{Polarisation and clarity}

Different expectations can be drawn regarding the impact of ideological polarisation between the government and the opposition on retrospective voting.

In line with the work on the importance of clarity of responsibility, the polarisation of available alternatives should make it easier for voters to distinguish government parties from opposition parties. If that is the case, stronger polarisation between the incumbent and the opposition should strengthen the reward-punishment mechanism. Previous work has indicated that a certain degree of polarisation helps voters to perceive the political landscape more clearly (Lachat, 2008; Lupu, 2015). Focusing on retrospective voting, the main distinction in the political landscape is the contrast between "the incumbent" and "the opposition" (Key, 1966). It can be expected that the mechanism of retrospective voting will be facilitated if incumbent and opposition parties are more ideologically distinct, as this will help voters to differentiate parties in government from parties in opposition. Indeed, 'the further apart the political parties, the easier it may be for citizens to distinguish among their electoral options' (Lupu, 2015: 356). Applied to the distinction between government and opposition, when the opposition is ideologically close to the government, voters might have a hard time to distinguish incumbent from opposition parties - reducing their ability to reward or punish the incumbent. If the parties are ideologically distinct, on the other hand, voters can more easily decide to reward parties for good performance or to punish for bad performance.

More polarisation should increase the clarity of responsibility even more, because it should become more clear to voters to what extent choosing an alternative (opposition) party can affect future policies in the country. As Gélineau and Singer (2015) argue, abandoning the incumbent party if it did not manage the economy well is less viable if it is not clear to the voter that other parties would make better economic policies. If a voter cannot clearly distinguish different parties because they are ideologically similar, they are unlikely to express dissatisfaction with incumbent policies by supporting the opposition: 'If the voter perceives little or no policy differences among party competitors, she has less reason to expect a reversal in policy outcomes even if a new government takes office' (Hellwig, 2010: 155; see also Gélineau and Singer, 2015). Polarisation in general, then, has been argued to render the 'issue 
packages' that parties offer more clear (Dalton, 2008; Ensley, 2007; Lachat, 2008). Hence, a higher degree of polarisation makes it more clear to the voters which policies each of the parties would pursue if they were in power, and thus makes more clear to voters how they can have similar policies if they are satisfied with the government's performance, or change policies if they are dissatisfied (Hellwig, 2010).

In summary, if voters are not satisfied with the way the country was governed during the last electoral term, they will want to change the direction of the government's policies in the future. This change is more likely to occur if they are able to vote for a party that they see as ideologically distinct from the governing party. When the opposition is ideologically distinct from the government, it is clear that voters can change the future direction of the government by punishing the incumbent and voting for the opposition. It is should be noted that we do not argue that dissatisfied voters will be more likely to vote for an certain party just because it is more ideologically distinguishable from other parties - i.e., right-wing (left-wing) voters voting for a left-wing (right-wing) party when they are dissatisfied - as this would be a spatial consideration. Rather, we argue that valence considerations will become more salient in deciding which party to vote for when parties are more easily distinguishable. While some voters might shift their vote to an ideologically different party, not all voters have to shift their votes from the incumbent to the opposition for there to be a punishment mechanism. Previous incumbent voters might be demobilized when the economy deteriorates, while the incumbent mobilizes their supporters to turn out to vote. Furthermore, those who previously voted for minor or centrist parties as well might strategically vote for another party to realize change. As a result, even if not a single voter switches ideological blocks, the mechanisms of mobilization and demobilization might result in the incumbent losing and the opposition winning votes.

For these reasons, our expectation is that ideological polarisation between the incumbent and the opposition will strengthen retrospective voting:

Hypothesis 1: The more ideologically distinct the opposition parties are from the government, the larger the effect of retrospective performance evaluations on the vote. 
While the Hypothesis is based on a clarity argument, it should be acknowledged that work in the field of social psychology would lead to a different hypothesis. Authors that conceive of partisanship as a social identity argue that polarization is associated with strong partisan identities, which lead - amongst others - to higher levels of bias and activism (Mason, 2015). As a result of this bias, partisans might not be able to evaluate the incumbent's work fairly, weakening performance voting

\section{Valence versus proximity}

In addition to the literature on clarity of responsibility, the valence literature as well can be looked at for theorising about the impact of polarisation of available alternatives on retrospective voting. Indeed, the performance of the incumbent can safely be considered a valence issue (Green and Jennings, 2012; Stokes, 1963).

From their introduction in the literature by Stokes (1963) onwards, valence issues have been contrasted with spatial models of voting that presume ideological proximity guides the vote choice (Sanders, Clarke, Stewart, and Whiteley, 2011). The relative importance of valence and spatial issues, has always intrigued electoral scholars, and it has been argued that contextual factors play an important role for understanding the extent to which valence issues matter.

In particular, it has been claimed that valence considerations gain importance when parties (and voters) converge (Green, 2007). In a series of analyses that focus on the British context, for example, the ideological convergence of parties has been found to co-occur with a growing weight of valence considerations in voters' choices (Green, 2007; Green and Hobolt, 2008). The mechanism linking party convergence and voting on the basis of valence considerations is the following: "voters who cannot determine which party is closer to them in policy terms, because parties offer similar policies, will more likely choose between parties on the basis of which can deliver' (Green and Hobolt, 2008: 461). Thus, when parties take diverse ideological positions, voters' ideological predispositions are an important determinant of their vote. If, however, parties cannot be ideologically distinguished, policy preferences cannot be used to distinguish between parties, and valence issues gain in importance (Buttice and Stone, 2012). Along these lines, we can formulate an alternative hypothesis about the moderating role of polarisation of alternatives on retrospective voting: 
Hypothesis 2: The more ideologically distinct the opposition parties are from the government, the smaller the effect of retrospective performance evaluations on the vote.

This hypothesis is in line with findings from the above-cited studies on valence issues. It is important to point out, however, that not all empirical work on the link between ideological convergence and valence voting supports the claim that when parties are ideologically more proximate, valence issues will matter more. Clark and Leiter (2014), investigating the conditioning effect of party polarisation on character-based attributes in nine Western democracies, find that ideological polarisation strengthens the impact of valence. Likewise, Pardos-Prado (2012) studies the determinants of voting behaviour in a set of European countries and finds that valence effects are stronger when party polarisation is high - in contrast to his expectations.

\section{Data and methods}

To test the hypotheses empirically, we use the data of the second and third module of the CSES project (CSES, 2015a, 2015b). Using these data allows us to test our hypotheses using a large sample of election studies from different countries representing different political contexts. ${ }^{1}$ The CSES data allow us to investigate retrospective voting with a focus on general performance evaluations (see below). For the dependent variable, we follow standard practice in the retrospective voting literature by distinguishing voters who voted for an incumbent party (code 1) and voters voting for an opposition party (code 0) (Lewis-Beck and Stegmaier, 2000). ${ }^{2}$

To test our hypotheses, two independent variables are of interest. The first is the voter's retrospective evaluation of the government's performance. Most previous research has focused on evaluations of the economy to investigate retrospective voting (Lewis-Beck and

\footnotetext{
${ }^{1}$ A full list of all elections under investigation is included in the Appendix.

${ }^{2}$ Some studies focus on voting for the lead party only (Kayser and Peress, 2012) which seems to lead to stronger effects of retrospective voting (Fisher and Hobolt, 2010). However, our argument builds on the theory of clarity of responsibility in which we have a specific interest in whether or not the government consisted of a coalition of multiple parties. Therefore, we follow standard practice and focus on the votes for all incumbent parties.
} 
Stegmaier, 2000, 2007). However, the economy is not the only issue voters care about, and previous research has shown that there is substantial variation in what issues voters consider the most important (Singer, 2011). We use a general performance question, that has also been used by previous research on retrospective voting (de Vries and Giger, 2014). The item asks voters to evaluate the performance of the government "in general": "Now thinking about the performance of the [government in [capital]/president] in general, how good or bad a job do you think the [government/president in [capital]] has done over the past [number of years since last government took office, before the current election] years? Has [it/he/she] done a very good job? A good job? A bad job? A very bad job?" This scale has been reversed so that higher values denote a more positive performance evaluation.

The second independent variable of interest is the moderating variable: the ideological polarisation of available alternatives. In the CSES questionnaire, voters were asked to position all main parties on an ideological axis running from 0 ("left") to 10 ("right"). Following previous research, we calculate ideological positions using voters' placements on this axis (Dassonneville and Dejaeghere, 2014; Hooghe and Stiers, 2017; Kölln and Polk, 2017; Lupu, 2015). ${ }^{3}$ As there might be concerns for endogeneity between voters' perceptions of the parties' ideological position, party choice, and perceptions of performance, we use the mean position of respondents within each election study as the party's position.

To test our arguments, we introduce a measure of polarisation of available alternatives that takes into account the polarisation between government and opposition within the political system. To construct this measure, we build on the polarisation measure of Lupu (2015 - building on Dalton (2008)). He measures polarisation by calculating the sum of the weighted squared distance of each party to the weighted average position of all parties. Similarly, we calculate the sum of the weighted squared distance of all opposition parties to the weighted government position:

\footnotetext{
${ }^{3}$ Others only use perceptions of the highest educated respondents to determine party positions (Dassonneville et al., 2019; Golder and Stramski, 2010). However, as the interest is in the whole sample of respondents, we argue that the perceptions of all respondents should be taken into account. Furthermore, research has indicated that using the perceptions of the whole sample results in more moderate party positions (Alvarez and Franklin, 1994), which makes for a conservative test for our measure of polarisation. It is reassuring to note, however, that results are generally very similar when using either perceptions of the highest educated respondents or those of the whole sample (Dassonneville et al., 2019).
} 
Dieter Stiers \& Ruth Dassonneville

$$
\bar{P}_{\text {alternatives }}=\sum_{i=1}^{m} \frac{V_{i}}{\sum_{i=1}^{m} V_{i}} \times\left(p_{i}-\bar{G}\right)^{2}
$$

in which:

$$
\bar{G}=\sum_{i=1}^{n} \frac{V_{i}}{\sum_{i=1}^{n} V_{i}} \times p_{i}
$$

in which $V_{i}$ denotes the vote share of the party in the previous election, and $p_{i}$ the position of the party on the left-right scale. While $m$ denotes the set of opposition parties, $n$ denotes the parties in government. Theoretically, this scale of polarisation of alternatives runs from 0 (all opposition parties have the same position as the governing parties) to 100 (the weighted government position is 0 (10) while all opposition parties are positioned on $10(0))$. The observed range is 0.197 to 30.699 . $^{4}$

This operationalisation of polarisation comes closest to our theoretical argument. While the theory of Anderson (2000) and Bengtsson (2004) focused on an alternative government being available, our main focus here is on the alternative parties - i.e., opposition parties - that the voter can choose from. By weighting the ideological positions by parties' vote shares, the relative size of all parties is taken into account. Furthermore, as Lupu (2015: 338-339) states, it acts as a proxy measure for each party's prominence in the system, and prevents artificially high values caused by small fringe parties - which most voters would most likely not assume to be viable alternatives. Finally, it takes into account previous research showing that the main opposition party is likely to receive more support from dissatisfied voters than smaller opposition parties (Williams at al., 2017; Plescia and Kritzinger, 2017).

After investigating the effect of our measure of polarisation of available alternatives, we test whether it contributes to explaining variation in retrospective voting when accounting for the explanations previous studies have offered. First, to test whether our measure explains heterogeneity in retrospective voting when accounting for standard indicators of clarity of responsibility, we include in our model the measure of government clarity as proposed by

\footnotetext{
${ }^{4}$ The correlation with the measure of polarisation of Lupu (2015) is 0.56 . Hence, while there is a substantial correlation between the two measures, they can be distinguished empirically.
} 
Hobolt et al. (2013). This measure includes (1) whether or not there was a coalition government, (2) whether or not there was cohabitation in semi-presidential regimes, (3) the ideological cohesion of the government, and (4) the dominance of the main governing party. We derive this information from ParlGov (Döring and Manow, 2018). As this measure is expected to moderate retrospective voting, we include it in the model in interaction with the retrospective performance evaluations. Second, we test whether our measure explains variation in retrospective voting when accounting for the findings of Anderson (2000). To do so, we include an interaction between retrospective performance evaluations and the Effective Number of Parliamentary Parties (ENPP) - derived from Gallagher (2017).

Next to these variables of interest, we include additional covariates to control for their impact on the party choice. First, we include standard socio-demographic variables. Age is included as the respondent's age in the election year. Sex is included with male voters as reference category. Educational level is included as categorical variable distinguishing (1) voters who did not complete secondary education (reference category), (2) respondents who completed secondary education, (3) respondents who received post-secondary vocational training an unfinished university training, and (4) respondents who obtained a university degree. We also include an indicator of whether or not the respondent is religious. ${ }^{5} \mathrm{Next}$, we include the income category of the respondent, divided in quintiles. Finally, we control for the voter's own ideological position, as the self-placement on an ideological scale running from 0 (left) to 10 (right).

Given the binary nature of the dependent variable, we use logistic regression models to predict the respondent's vote for an incumbent party. However, our data come from different election studies, and the observations within elections cannot be considered to be independent of each other. We take this clustering into account by estimating multilevel models (Gelman and Hill, 2007). More specifically, we estimate random-intercept models with individual voters nested in election studies. As we expect that the polarisation of available alternatives moderates retrospective voting, we interact our measure of polarisation with the voter's retrospective performance evaluation. We add a random slope for the individual-level

\footnotetext{
${ }^{5}$ In the election studies in which the measure is available, we include religiosity as the answers on a four-point scale ranging from "no religious beliefs" to "very religious". In the other election studies, we measure religiosity using the answers on a scale measuring how frequently the respondent attends religious services, ranging from "never" to "once a week".
} 
performance evaluations in the models including cross-level interactions. Furthermore, to rule out effects of differences in distributions between countries, we center all continuous individual-level variables around their respective group means.

\section{Results}

The results of our multilevel logistic regression models are summarized in Table 1. First, we investigate the effect of the polarisation of alternatives on retrospective voting. Then, we test the robustness of the findings when controlling for variables that previous research has found to moderate retrospective voting.

In model 1 of Table 1 we investigate the direct impact of our variables of interest. The results suggest a strong and positive impact of retrospective performance evaluations on the vote: the more satisfied a voter is with the government's performance, the more likely this voter will be to vote for an incumbent party. While a voter who has the most negative evaluation of the government's performance has a predicted probability of 4.27 per cent to vote for the government, this increases up to 90.80 per cent for the most positive voters. Hence, the classic retrospective voting theory is supported by the analyses. ${ }^{6}$

We are mainly interested in the conditional effect of retrospective performance evaluations by the polarisation of available alternatives. To test our hypotheses, we include an interaction between retrospective performance evaluations and our polarisation measure (Model 2). The interaction coefficient is significantly positive - indicating that the larger the degree of ideological polarisation between government and opposition, the larger the impact of retrospective performance evaluation on the vote for an incumbent. Vice versa, dissatisfied voters will punish the incumbent parties to a larger extent when the alternatives are clear.

As coefficients of logistic models are hard to interpret at face value, we calculate conditional marginal effects. Figure 1 displays the average marginal effect of retrospective evaluations of

\footnotetext{
${ }^{6}$ Some might interpret this strong effect as indicating a problem of reverse causality between performance evaluations and the vote. To control for endogeneity to some extent, and to test whether the model presented here suffers from omitted variable bias, we replicated the analyses including an indicator of whether or not the voter identifies with an incumbent party. The results are reported in Appendix B and support the conclusions presented here. Furthermore, we tested the robustness of our findings using purged performance evaluations. As will be noted below, the findings of this additional test are summarized in Appendix $\mathrm{H}$.
} 


\section{Dieter Stiers \& Ruth Dassonneville}

the government's performance at different levels of polarisation, which further clarifies the positive interaction effect. ${ }^{7}$ Retrospective performance evaluations have a positive impact on the vote for an incumbent party, and the higher the degree of ideological polarisation between government and opposition, the larger the effect of performance evaluations on the vote. Hence, both reward and punishment of the incumbent government is facilitated by high levels of ideological polarisation between incumbent and opposition parties.

\footnotetext{
${ }^{7}$ The Figure also shows that some cases seem to be scoring exceptionally high on the polarisation scale. These cases are Bulgaria 2001 and Hungary 2002. As a robustness test, we conducted the analyses excluding these two elections, and this did not alter the substantial results.
} 
Dieter Stiers \& Ruth Dassonneville

Table 1: Multilevel logistic regression models predicting incumbent voting

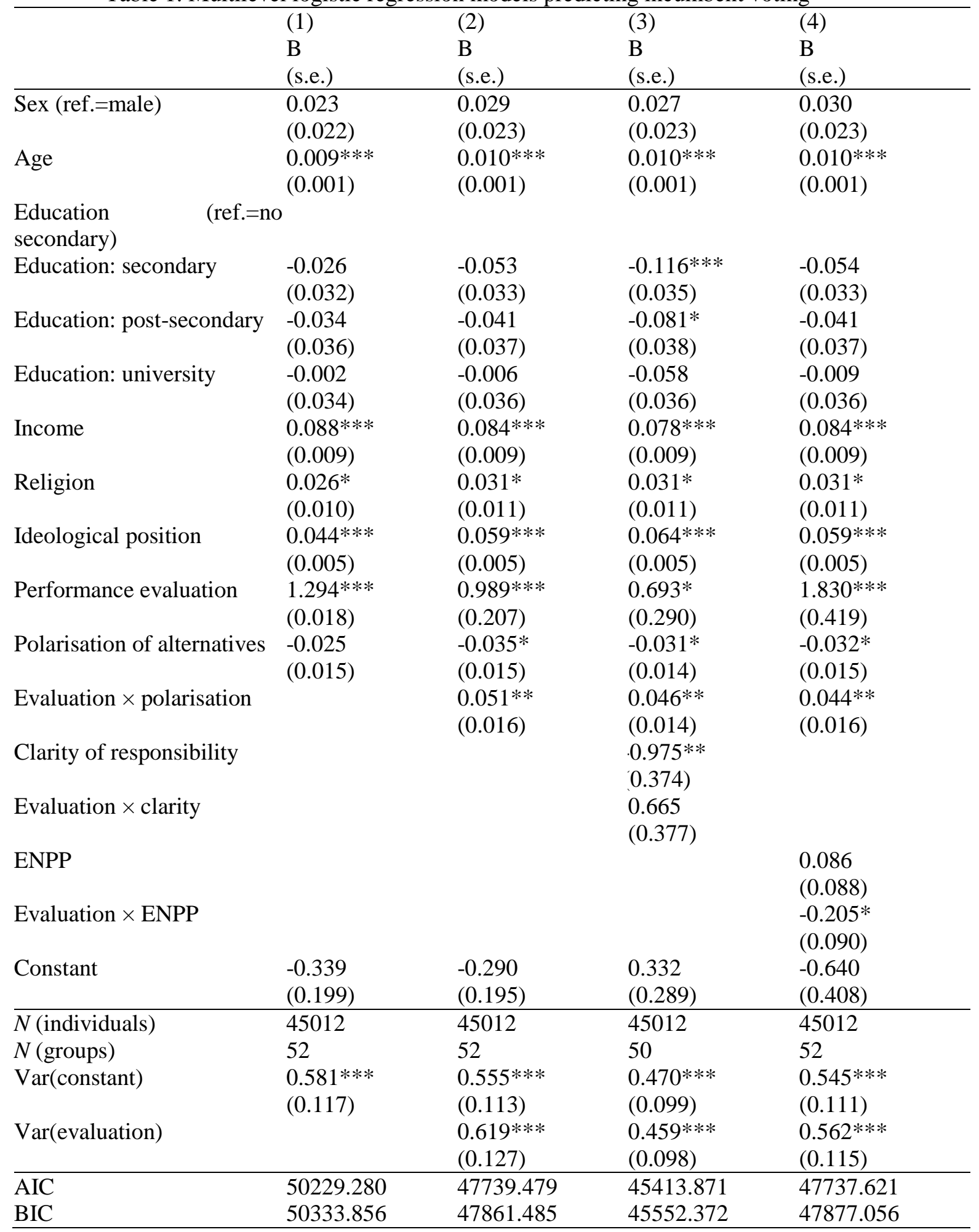

Note: Entries are log-odds coefficients, standard errors reported in parentheses. Data: CSES Module 2 and 3. Significance levels: ${ }^{*}: p<0.05 ;{ }^{* *}: p<0.01{ }^{* * * *}: p<0.001$. 
Figure 1: Average marginal effect of performance evaluations at different values of ideological polarisation between government and opposition.

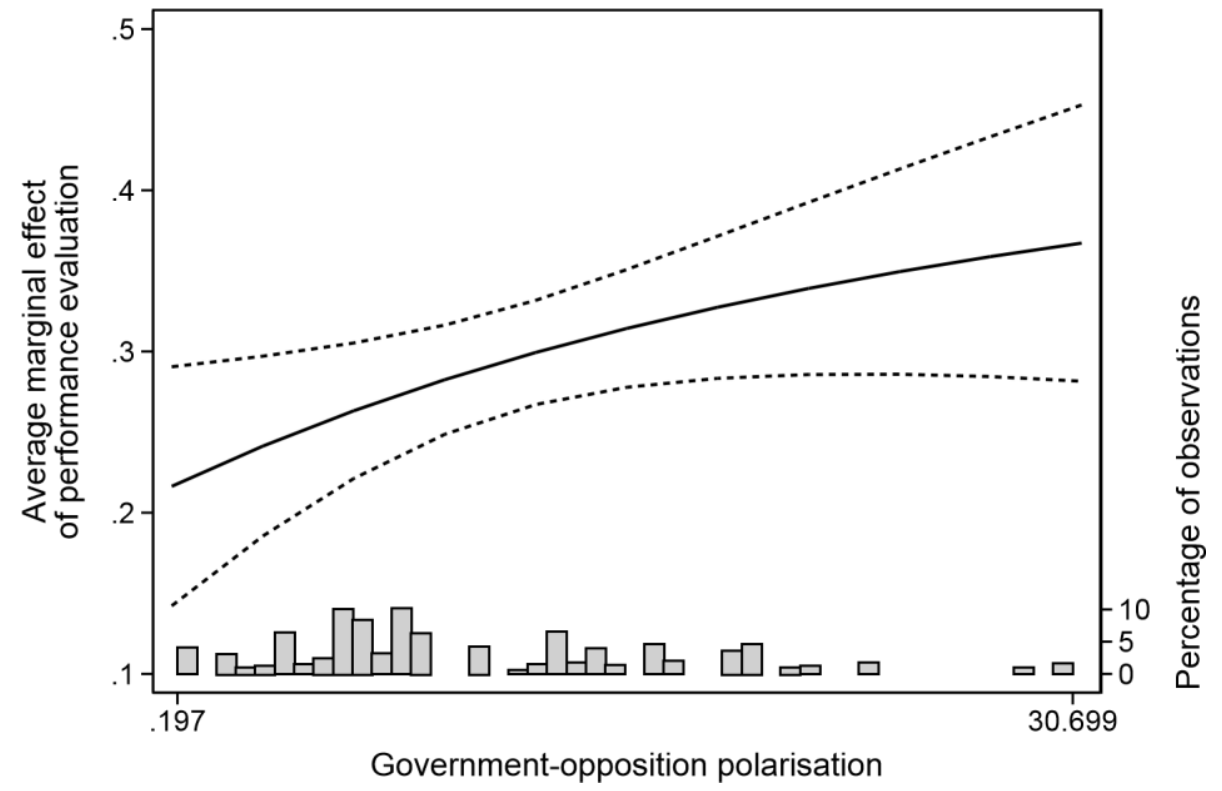

Note: the figure shows the average marginal effect and $95 \%$ confidence intervals of retrospective performance evaluations based on Model 2 in Table 1. Data: CSES 2, CSES 3.

Our results are in line with our first hypothesis, that is inspired by the clarity of responsibility literature. In contrast, our analyses lead us to reject the second hypothesis. Like earlier comparative work on the interaction between ideological positions and the effect of valence issues, we fail to find that such issues matter most when parties are ideologically close.

Next, we turn to investigating whether our measure of polarisation helps explaining variation in retrospective voting when controlling for the measures that were proposed by earlier research. In Model 3 in Table 1, we test whether our measure of polarisation has an effect separate of the clarity of responsibility of the political context. To do so, we include an interaction between performance evaluations and the clarity of the context. If the polarisation of available alternatives matters only because it increases the clarity to the voter, the interaction between performance evaluations and polarisation should be rendered nonsignificant. While the interaction between performance evaluations and polarisation remains significant, the interaction of evaluations and clarity of responsibility is not significant. ${ }^{8}$

\footnotetext{
${ }^{8}$ Note that this interaction reaches conventional thresholds of statistical significance if the interaction between evaluations and polarisation is not included in the model.
} 
Hence, our results seem to be robust to controlling for government clarity. Next, we test whether our argument differs from previous findings of the Effective Number of Parliamentary Parties to moderate retrospective voting. The results of Model 4 show that our measure of polarisation helps explaining variation in retrospective voting on top of this measure. Hence, polarisation adds to explaining heterogeneity in retrospective voting and complements the roles of the clarity of the context and the effective number of parliamentary parties in the country.

Besides the analyses presented here, we conducted a series of additional analyses to test the robustness of our findings. As most previous research on retrospective voting focused on the economy, we replicated our models using economic perceptions. We also tested a series of alternative measures of the key variables of interest in our models - i.e., the polarisation of available alternatives, government clarity, and control variables. We also tested whether our results hold in different subgroups. The results of these robustness tests are summarized in the online Appendix, and provide support for the findings presented here.

One issue that deserves special attention, however, is that of endogeneity in subjective perceptions of the government's performance. While we model performance evaluations as a predictor of incumbent or opposition party support, others have argued that the relationship might be reciprocal, and that party preferences influence perceptions of performance. Instead of being a true evaluation of the government's performance, the evaluation item could thus be tapping partisan differences in feelings towards the incumbent parties (Evans \& Andersen, 2006; Evans \& Pickup, 2010). To verify that our results reflect actual differences in retrospective voting rather than the reciprocal relationship between party support and perceptions of performance, it is important to account for such endogeneity. To test whether our results are subject to endogeneity, we purged the performance evaluation (Duch, Palmer, \& Anderson, 2000; Duch \& Stevenson, 2008). This method consists of three steps, in which the biased part of performance evaluations are separated from the reality-based part by means of a series of consecutive regression models. The results of this additional test are reported in Appendix $\mathrm{H}$ and show that, when relying on purged performance evaluations, we still find that higher levels of ideological polarisation facilitate retrospective voting. 
Dieter Stiers \& Ruth Dassonneville

\section{Conclusion}

This study set out to investigate the impact of the polarisation of available alternatives on retrospective voting. Previous research on clarity of responsibility has already indicated that characteristics of a political system - and of the incumbent government in particular - can facilitate retrospective voting. However, one aspect that remained largely unstudied is the role of the alternative parties the voter can choose from. In this paper, we argue that the ideological distinctness - i.e., the polarisation - of government and opposition parties influences the extent to which voters relate their performance evaluations to their vote.

The literature on the influence of polarisation on voting behaviour led us to two alternative hypotheses. First, the literature on retrospective voting leads to the expectation that polarisation should enhance retrospective voting. If government and opposition are more ideologically distinct, it is easier for voters to distinguish incumbent from opposition parties, and hence to vote according to their evaluation of the incumbent's track record. Furthermore, if government and opposition are more ideologically distinct, a voter who is dissatisfied with the government's past policies has a better opportunity to change the future direction of policies. Hence, if government and opposition are polarized, a vote for the opposition becomes a more efficient tool to punish the government. However, theoretical accounts on the role of valence issues on the vote lead to the opposite expectation - that valence issues gain in importance when parties converge ideologically - and hence that they have less importance in polarized settings.

Our analyses on the data of the second and third module of the CSES project provide support for our first hypothesis. By relying on a novel measure of the polarisation of available alternatives, we find strong positive moderation effects: the larger the degree of polarisation between government and opposition, the larger the effect of retrospective performance evaluations on the vote. Furthermore, we find that this measure helps explaining variation in retrospective voting on top of the measures previous research has identified. Hence, including the polarisation of available alternatives adds to our understanding of the heterogeneity in retrospective voting. Furthermore, while this finding is in contrast with the theoretical accounts on the importance of valence issues on the vote, it is in line with recent empirical research in this field that showed that valence issues seem to matter more in polarized settings. 
Our study is subject to some limitations. Most importantly, while some previous studies on the importance of valence issues in the vote choice process take a longitudinal approach, we are limited to using cross-sectional data. Second, while we argue that higher clarity of responsibility helps voters to distinguish parties and that voters get a better choice for alternative policies in the future, we remain unsure of the causal underpinnings of our results. Future research could examine the causal process behind the moderating effect of polarisation documented here. Finally, we did not take into account the possible reciprocal relationship between polarisation and differences in performance evaluations between out-and in-partisans. While we argue that retrospective voting is inhibited or facilitated by polarisation, increasing levels of polarisation between parties might also affect the extent to which partisans are willing to credit incumbents from another party, or punish their own. While Donovan et al. (forthcoming) provide evidence for this hypothesis in the U.S. case, it is up to future research to investigate the effects of this trend for the findings presented here.

Despite these limitations, the results hold strong implications for the way in which elections work as a means of rewarding or sanctioning the incumbent for its policies. From a democratic point of view, retrospective voting is a desirable mechanism, as it provides a venue for voters to ensure that parties are responsive to their demands. While negative accounts of increasing levels of polarisation between political parties are plenty, our results allow for more optimism. At least with the data at hand, it seems like a larger degree of ideological polarisation between the government and the opposition makes it easier for voters to reward and punish the incumbent government according to its performance.

\section{References}

Alvarez, Michael R. and Charles H. Franklin. 1994. "Uncertainty and Political Perceptions.” Journal of Politics 56 (3): 671-688.

Anderson, Christopher J. 2000. "Economic Voting and Political Context: A Comparative Perspective.” Electoral Studies 19 (2): 151-170.

Anderson, Christopher J. 2007. "The End of Economic Voting? Contingency Dilemmas and the Limits of Democratic Accountability.” Annual Review of Political Science 10: 271-296. 
Dieter Stiers \& Ruth Dassonneville

Bengtsson, Åsa. 2004. "Economic Voting: The Effect of Political Context, Volatility and Turnout on Voters' Assignment of Responsibility.” European Journal of Political Research 43 (5): 749-767.

Buttice, Matthew K. and Walter J. Stone. 2012. "Candidates Matter: Policy and Quality Differences in Congressional Elections.” Journal of Politics 74 (3): 870-887.

Clark, Michael and Debra Leiter. 2014. "Does the Ideological Dispersion of Parties Mediate the Impact of Valence? A Cross-National Study of Party Support in Nine Western European Democracies.” Comparative Political Studies 47 (2): 171-202.

CSES. 2015a. The Comparative Study of Electoral Systems (www.cses.org). CSES MODULE 2 FULL RELEASE [dataset]. December 15, 2015 version. doi:10.7804/cses.module2.2015-1215.

CSES. 2015b. The Comparative Study of Electoral Systems (www.cses.org). CSES MODULE 3 FULL RELEASE [dataset]. December 15, 2015 version. doi:10.7804/cses.module3.2015-1215.

Dalton, Russell J. 2008. “The Quantity and the Quality of Party Systems. Party System Polarization, Its Measurement, and Its Consequences.” Comparative Political Studies 41 (7): 899-920.

Dassonneville, Ruth and Yves Dejaeghere. 2014. "Bridging the Ideological Space: A CrossNational Analysis of the Distance of Party Switching.” European Journal of Political Research 53 (3): 580-599.

Dassonneville, Ruth, Fernando Feitosa, Marc Hooghe, Richard R. Lau and Dieter Stiers. 2019. “Compulsory Voting Rules, Reluctant Voters and Ideological Proximity Voting." Political Behavior 41 (1): 209-230.

de Vries, Catherine. E. and Nathalie Giger. 2014. "Holding Governments Accountable? Individual Heterogeneity in Performance Voting.” European Journal of Political Research 53 (2): 345362.

Döring, H., and Manow, P. 2018. Parliaments and governments database (ParlGov): Information on parties, elections and cabinets in modern democracies. Development version.

Donovan, Kathleen, Paul M. Kellstedt, Ellen M. Key and Matthew J. Lebo. forthcoming. "Motivated Reasoning, Public Opinion, and Presidential Approval.” Political Behavior, forthcomings.

Duch, Raymond. 2001. “A Developmental Model of Heterogeneous Economic Voting in New Democracies."American Political Science Review 95 (4): 895-910. 
Dieter Stiers \& Ruth Dassonneville

Duch, Raymond and Randolph T. Stevenson. 2008. The Economic Vote: How Political and Economic Institutions Condition Election Results. New York: Cambridge University Press.

Duch, Raymond, Harvey D. Palmer and Christopher J. Anderson. 2000. "Heterogeneity in Perceptions of National Economic Conditions.” American Journal of Political Science 44 (4): $635-652$.

Ecker, Alejandro, Konstantin Glinitzer and Thomas M. Meyer. 2016. "Corruption Performance Voting and the Electoral Context.” European Political Science Review 8 (3): 333-354.

Ensley, Michael J. 2007. "Candidate Divergence, Ideology, and Vote Choice in U.S. Senate Elections.” American Politics Research 35 (1):103-122.

Fiorina, Morris P. (1981). Retrospective Voting in American National Elections. New Haven: Yale University Press.

Fisher, Stephen D., and Sarah B. Hobolt. 2010. "Coalition Government and Electoral Accountability." Electoral Studies 29 (3): 358-369.

Gallagher, $\quad$ M. 2017. Election indices dataset at http://www.tcd.ie/PoliticalScience/staff/michael\%20gallagher/ElSystems/\%20accessed\%202 $6 / 03 / 2018$

Gasper, John T. and Andrew Reeves. 2011. "Make It Rain? Retrospection and the Attentive Electorate in the Context of Natural Disasters.” American Journal of Political Science 55 (2): 340-355.

Gélineau, François and Matthew M. Singer. 2015. "The Economy and Incumbent Support in Latin America.” In R. E. Carlin, M. M. Singer, \& E. J. Zechmeister (Eds.), The Latin American Voter. Pursuing Representation and Accountability in Challenging Contexts (pp. 281-299). Ann Arbor: University of Michigan Press.

Gelman, Andrew and Jennifer Hill. 2007. Data Analysis Using Regression and Multilevel/Hierarchical Models. Cambridge: Cambridge University Press.

Golder, Matt and Jacek Stramski. 2010. "Ideological Congruence and Electoral Institutions." American Journal of Political Science 54 (1): 90-106.

Green, Jane. 2007. "When Voters and Parties Agree: Valence Issues and Party Competition." Political Studies 55 (3): 629-655.

Green, Jane and Sarah B. Hobolt. 2008. “Owning the Issue Agenda: Party Strategies and Vote Choices in British Elections.” Electoral Studies 27 (3): 460-476. 
Dieter Stiers \& Ruth Dassonneville

Green, Jane and Will Jennings. 2012. “The Dynamics of Issue Competence and Vote for Parties In and Out of Power: An Analysis of Valence in Britain, 1979-1997." European Journal of Political Research 51 )(: 469-503.

Healy, Andrew and Neil Malhotra. 2013. "Retrospective Voting Reconsidered.” Annual Review of Political Science 16: 285-306.

Hellwig, Timothy T. 2010. “Context, Information, and Performance Voting.” In R. J. Dalton \& C. J. Anderson (Eds.), Citizens, Context, and Choice: How Context Shapes Citizens' Electoral Choices (pp. 149-175). New York: Oxford University Press.

Hobolt, Sarah B., James Tilley and Susan Banducci. 2013. "Clarity of Responsibility: How Government Cohesion Conditions Performance Voting.” European Journal of Political Research 52 (2): 164-187.

Hooghe, Marc and Dieter Stiers. 2017. "Do Reluctant Voters Vote Less Accurately? The Effect of Compulsory Voting on Party-Voter Congruence in Australia and Belgium." Australian Journal of Political Science 52 (1): 75-94.

Karol, David and Edward Miguel. 2007. "The Electoral Cost of War: Iraq Casualties and the 2005 U.S. Presidential Election.” Journal of Politics 69 (3): 633-648.

Kayser, Mark A. and Michael Peress. 2012. "Benchmarking across Borders: Electoral Accountability and the Necessity of Comparison.” American Political Science Review 106 (3): 661-684.

Key, Valdimer O. 1966. The Responsible Electorate. Rationality in Presidential Voting 1936-1960. Cambridge: Belknap Press of Harvard University Press.

Kölln, Ann-Kristin and Jonathan Polk. 2017. "Emancipated Party Members: Examining Ideological incongruence Within Political Parties.” Party Politics 23 (1): 18-29.

Lachat, Romain 2008. “The Impact of Party Polarization on Ideological Voting.” Electoral Studies 27 (4): 687-698.

Lewis-Beck, Michael S. and Mary Stegmaier. 2000. Economic Determinants of Electoral Outcomes. Annual Review of Political Science 3: 183-219.

Lupu, Noam. 2015. "Party Polarization and Mass Partisanship: A Comparative Perspective." Political Behavior 37 (2): 331-356.

Mason, Lilliana. 2014. "I Disrespectfully Agree"”: The Differential Effects of Partisan Sorting on Social and Issue Polarization.” American Journal of Political Science 59 (1): 128-145. 
Dieter Stiers \& Ruth Dassonneville

Nadeau, Richard, Michael S. Lewis-Beck and Éric Bélanger. 2012. "Economics and Elections Revisited." Comparative Political Studies 46 (5): 551-573.

Nadeau, Richard, Richard G. Niemi and Antoine Yoshinaka. 2002. "A Cross-National Analysis of Economic Voting: Taking Account of the Political Context Across Time and Nations." Electoral Studies 21 (3): 403-423.

Nannestad, Peter and Martin Paldam. 1994. "The VP-Function: A Survey of the Literature on Vote and Popularity Functions After 25 Years.” Public Choice 79 (3): 213-245.

Pardos-Prado, Sergi. 2012. "Valence Beyond Consensus: Party Competence and Policy Dispersion from a Comparative Perspective.” Electoral Studies 31 (2): 342-352.

Plescia, Carolina and Sylvia Kritzinger. 2017. "Retrospective Voting and Party Support at Elections: Credit and Blame for Government and Opposition.” Journal of Elections, Public Opinion and Parties 27 (2): 156-171.

Powell, Bingham G. and Guy D. Whitten. 1993. "A Cross-National Analysis of Economic Voting: Taking Account of the Political Context.” American Journal of Political Science 37 (2): 391414.

Przeworski, Andrew, Susan C. Stokes and Bernard Manin. (Eds.). 1999. Democracy, Accountability, and Representation. Cambridge: Cambridge University Press.

Sanders, David, Harold D. Clarke, Marianne C. Stewart and Paul Whiteley. 2011. "Downs, Stokes and the Dynamics of Electoral Choice.” British Journal of Political Science 41 (2): 287-314.

Schwindt-Bayer, Leslie A. and Margit Tavits. 2016. Clarity of Responsibility, Accountability, and Corruption. Cambridge: Cambridge University Press.

Silva, Thiago and Guy D. Whitten. 2017. "Clarity of Responsibility and Vote Choice." In Kai Arzheimer, Jocelyn Evans and Michael S. Lewis-Beck (Eds.), The Sage Handbook of Political Behaviour (pp. 80-91). London: Sage.

Singer, Matthew M. 2011. "Who Says "It's the Economy"? Cross-National and Cross-Individual Variation in the Salience of Economic Performance.” Comparative Political Studies 44 (3): 284-312.

Stiers, Dieter. Forthcoming. Beyond the Distinction Incumbent-Opposition: Retrospective Voting on the Level of Political Parties. Party Politics, forthcoming.

Stokes, Donald E. 1963. "Spatial models and party competition.” American Political Science Review 57 (2): 368-377. 
Dieter Stiers \& Ruth Dassonneville

Strøm, Kaare. 2000. "Delegation and Accountability in Parliamentary Democracies.” European Journal of Political Research 37 (3): 261-290.

Tilley, James Sarah B. and Hobolt. 2011. "Is the Government to Blame? An Experimental test of how Partisanship Shapes Perceptions of Performance and Responsibility.” Journal of Politics 73 (3): 316-330.

Whitten, Guy D. and Harvey D. Palmer. 1999. "Cross-National Analyses of Economic Voting." Electoral Studies 18 (1): 49-67.

Williams, Laron K., Mary Stegmaier and Marc Debus. 2017. "Relaxing the Constant Economic Vote Restriction: Economic Evaluations and Party Support in Germany.” Party Politics 23 (3): 286-296.

\section{$\underline{\text { Appendices }}$}

To test the robustness of the findings, we challenge our models in several ways. First, our demonstration is based on analysis of performance voting that uses an indicator of citizens' evaluations of government performance in general. However, most previous research in the field of retrospective voting and work on the moderating role of clarity of responsibility has studied the effects of economic perceptions. We would have liked to replicate the results in Table 1 of the manuscript when replacing the general performance measure for a measure of respondents' retrospective and sociotropic economic evaluations. However, such a measure is not included in the second and third module of the CSES - which are the modules used for the analyses reported in Table 1. Fortunately, the first and fourth module of the CSES project did include such an item of citizens' economic perceptions, and can hence be used to test whether our results are confirmed using evaluations of the economy. Appendix $\mathrm{C}$ reports the results of these analyses, using the data from the first and fourth modules of the CSES project. The results are in line with the findings reported in the main text: more positive economic evaluations positively affect the likelihood of voting for the incumbent, and this effect is strengthened when the polarisation of available alternatives increases.

Second, we tested the robustness of the results that are reported in Table 1 of the manuscript when slightly changing the coding of different key variables. Focusing on our key independent variable first, to construct our indicator of the polarization of the alternatives we 
make use average positions of every party (see Equation 1). However, the variation in perceived party positions provides a useful source of individual-level variation. Hence, we also estimated the models using each voter's individual perceptions of the ideological position of the parties. The results of these analyses are reported in Appendix D. Surprisingly, the coefficients are smaller than those reported in Table 1. However, our conclusions still hold when using this alternative measure, as the interaction between performance evaluations and the perceived polarisation of available alternatives remains statistically significant. Second, the overall cohesion of the government parties has a mechanical effect on our polarisation measure: the more ideologically diverse the government is, the more likely it is that the mean position of the government is close to several opposition parties. While we control for this to some extent in the main models - as government cohesion is part of the clarity of responsibility index - including this element in a broader index might blur its effect. Therefore, we replicated our analyses using only the indicator of the cohesion of the government as a control for the clarity of responsibility. The results, reported in Appendix E, are in line with the conclusions presented in the main text. Third, the models include different covariates to control for their impact on the vote, but for most of these variables, we expect different directions of effects depending on the ideological leanings of the incumbent parties. As a robustness test, we therefore also conducted the analyses while adjusting the direction of the coding of the variables to the ideological position of the main incumbent party (see Nadeau, Lewis-Beck, \& Bélanger, 2012). The results, reported in Appendix F, are largely in line with the conclusions reported in the main text; the main difference is that the interaction between performance evaluations and clarity of responsibility (as reported in Model 3 of Table 1) turns statistically significant.

We also tested whether our results hold in different subgroups. As previous research has indicated the important role of political sophistication in retrospective voting (de Vries \& Giger, 2014), we replicated our analyses for the least- and most-knowledgeable groups separately. The results, reported in Appendix G, are in line with the results reported in the main text in both groups of voters.

Finally, as indicated in the main text, we control for endogeneity in perceptions of government performance using the method introduced by Duch, Palmer, and Anderson (2000) and Duch and Stevenson (2008). The results are summarised in Appendix H. 
Dieter Stiers \& Ruth Dassonneville 
Dieter Stiers \& Ruth Dassonneville

\section{Appendix A: Election studies included in the analyses}

Table 1: Election studies included in the analyses

\begin{tabular}{l|l}
\hline Country & Year \\
\hline Australia & 2004,2007 \\
Austria & 2008 \\
Bulgaria & 2001 \\
Canada & 2004,2008 \\
Croatia & 2007 \\
Czech Republic & $2002,2006,2010$ \\
Germany & $2002,2005,2009$ \\
Denmark & 2001 \\
Spain & 2004,2008 \\
Estonia & 2011 \\
Finland & $2003,2007,2011$ \\
France & 2007 \\
Great Britain & 2005 \\
Greece & 2009 \\
Hungary & 2002 \\
Ireland & 2002,2007 \\
Iceland & $2003,2007,2009$ \\
Israel & 2006 \\
Italy & 2006 \\
the Netherlands & 2002 \\
New Zealand & 2002,2008 \\
Poland & $2001,2005,2007$ \\
Portugal & $2002,2005,2009$ \\
Romania & 2004 \\
Slovakia & 2008 \\
Slovenia & 2004,2008 \\
Sweden & 2002,2006 \\
Switzerland & 2003,2007 \\
Turkey & 2001 \\
United States of America & 2004,2008 \\
\hline
\end{tabular}


Dieter Stiers \& Ruth Dassonneville

\section{Appendix B: Results including party ID with incumbent}

Table B.1: Replication of Table 1 in the text including incumbent party identification

\begin{tabular}{|c|c|c|c|c|}
\hline & $\begin{array}{l}(1) \\
B\end{array}$ & $\begin{array}{l}\text { (2) } \\
B\end{array}$ & $\begin{array}{c}\text { (3) } \\
B\end{array}$ & $\begin{array}{l}\text { (4) } \\
B\end{array}$ \\
\hline \multirow[t]{2}{*}{ Sex (ref.=male) } & $0.064^{*}$ & $0.071^{*}$ & $0.074^{*}$ & $0.071^{*}$ \\
\hline & $(0.031)$ & $(0.032)$ & $(0.033)$ & $(0.032)$ \\
\hline \multirow[t]{2}{*}{ Age } & $0.005^{* * *}$ & $0.006^{* * * *}$ & $0.005^{* * *}$ & $0.006^{* * *}$ \\
\hline & $(0.001)$ & $(0.001)$ & $(0.001)$ & $(0.001)$ \\
\hline \multicolumn{5}{|l|}{ Education (ref.=no secondary) } \\
\hline \multirow[t]{2}{*}{ Education: secondary } & -0.061 & -0.087 & $-0.153^{* *}$ & -0.087 \\
\hline & $(0.046)$ & $(0.047)$ & $(0.048)$ & $(0.047)$ \\
\hline \multirow[t]{2}{*}{ Education: post-secondary } & -0.054 & -0.050 & -0.084 & -0.051 \\
\hline & $(0.051)$ & $(0.052)$ & $(0.053)$ & $(0.052)$ \\
\hline \multirow[t]{2}{*}{ Education: university } & -0.020 & -0.021 & -0.076 & -0.021 \\
\hline & $(0.048)$ & $(0.049)$ & $(0.050)$ & $(0.049)$ \\
\hline \multirow[t]{2}{*}{ Income } & $0.052^{* * *}$ & $0.049^{* * *}$ & $0.047^{* * *}$ & $0.049^{* * *}$ \\
\hline & $(0.012)$ & $(0.013)$ & $(0.013)$ & $(0.013)$ \\
\hline \multirow[t]{2}{*}{ Religion } & $-0.046^{* *}$ & $-0.039^{* *}$ & $-0.040^{* *}$ & $-0.039^{* *}$ \\
\hline & $(0.015)$ & $(0.015)$ & $(0.015)$ & $(0.015)$ \\
\hline \multirow[t]{2}{*}{ Ideological position } & $0.027^{* * *}$ & $0.036^{* * *}$ & $0.037^{* * * *}$ & $0.036^{* * *}$ \\
\hline & $(0.007)$ & $(0.007)$ & $(0.007)$ & $(0.007)$ \\
\hline \multirow[t]{2}{*}{ Incumbent PID } & $3.723^{* * *}$ & $3.627^{* * *}$ & $3.641^{* * *}$ & $3.626^{* * *}$ \\
\hline & $(0.040)$ & $(0.041)$ & $(0.042)$ & $(0.041)$ \\
\hline \multirow[t]{2}{*}{ Performance evaluation } & $0.947^{* * *}$ & $0.724^{* * *}$ & $0.652^{*}$ & $1.227^{* * *}$ \\
\hline & $(0.025)$ & $(0.177)$ & $(0.260)$ & $(0.366)$ \\
\hline \multirow[t]{2}{*}{ Polarisation of alternatives } & -0.023 & -0.028 & -0.025 & -0.025 \\
\hline & $(0.019)$ & $(0.018)$ & $(0.018)$ & $(0.018)$ \\
\hline \multirow[t]{2}{*}{ Evaluation $\times$ polarisation } & & $0.032^{*}$ & $0.030^{*}$ & $0.028^{*}$ \\
\hline & & $(0.014)$ & $(0.013)$ & $(0.014)$ \\
\hline \multirow[t]{2}{*}{ Clarity of responsibility } & & & -0.743 & \\
\hline & & & $(0.470)$ & \\
\hline \multirow[t]{2}{*}{ Evaluation $\times$ clarity } & & & 0.238 & \\
\hline & & & $(0.335)$ & \\
\hline \multirow[t]{2}{*}{ ENPP } & & & & 0.086 \\
\hline & & & & $(0.106)$ \\
\hline \multirow[t]{2}{*}{ Evaluation $\times$ ENPP } & & & & -0.122 \\
\hline & & & & $(0.078)$ \\
\hline \multirow[t]{2}{*}{ Constant } & $-1.660^{* * *}$ & $-1.608^{* * * *}$ & $-1.106^{* *}$ & $-1.959^{* * * *}$ \\
\hline & $(0.247)$ & $(0.237)$ & $(0.367)$ & $(0.496)$ \\
\hline$N$ (individuals) & 37230 & 37230 & 35274 & 37230 \\
\hline \multirow{3}{*}{$\begin{array}{l}N \text { (groups) } \\
\operatorname{Var}(\text { constant })\end{array}$} & 52 & 52 & 50 & 52 \\
\hline & $0.873^{* * *}$ & $0.801^{* * * *}$ & $0.738^{* * *}$ & $0.791^{* * * *}$ \\
\hline & $(0.176)$ & $(0.163)$ & $(0.154)$ & $(0.161)$ \\
\hline \multirow[t]{2}{*}{ Var(evaluation) } & & $0.417^{* * *}$ & $0.332^{* * *}$ & $0.398^{* * * *}$ \\
\hline & & $(0.091)$ & $(0.076)$ & $(0.087)$ \\
\hline$A I C$ & 27649.250 & 26904.541 & 25713.079 & 26905.533 \\
\hline$B I C$ & 27760.073 & 27032.414 & 25857.085 & 27050.456 \\
\hline
\end{tabular}

Note: Entries are log-odds coefficients, standard errors reported in parentheses. Data: CSES Module 2 and 3. Significance levels: ${ }^{*}: p<0.05 ;{ }^{* *}: p<0.01 ;^{* * *}: p<0.001$. 
Dieter Stiers \& Ruth Dassonneville

\section{Appendix C: replication of the results using economic perceptions}

Table C.1: Replication of Table 1 in the text using economic evaluations

\begin{tabular}{|c|c|c|c|c|}
\hline & $\begin{array}{c}(1) \\
\text { B } \\
\text { (s.e.) }\end{array}$ & $\begin{array}{l}(2) \\
\text { B } \\
\text { (s.e.) }\end{array}$ & $\begin{array}{l}\text { (3) } \\
\text { B } \\
\text { (s.e.) }\end{array}$ & $\begin{array}{l}\text { (4) } \\
\text { B } \\
\text { (s.e.) }\end{array}$ \\
\hline Sex (ref.=male) & $\begin{array}{c}0.165^{* * *} \\
(0.026)\end{array}$ & $\begin{array}{c}0.158^{* * *} \\
(0.026)\end{array}$ & $\begin{array}{c}0.158^{* * *} \\
(0.026)\end{array}$ & $\begin{array}{c}0.158^{* * *} \\
(0.026)\end{array}$ \\
\hline Age & $\begin{array}{c}0.005^{* * * *} \\
(0.001)\end{array}$ & $\begin{array}{c}0.005^{* * *} \\
(0.001)\end{array}$ & $\begin{array}{l}0.005^{* * *} \\
(0.001)\end{array}$ & $\begin{array}{l}0.005^{* * *} \\
(0.001)\end{array}$ \\
\hline Education (ref.=primary) & & & & \\
\hline Education: secondary & $\begin{array}{l}-0.063 \\
(0.037)\end{array}$ & $\begin{array}{l}-0.074^{*} \\
(0.037)\end{array}$ & $\begin{array}{l}-0.075^{*} \\
(0.037)\end{array}$ & $\begin{array}{l}-0.074^{*} \\
(0.037)\end{array}$ \\
\hline Education: tertiary & $\begin{array}{l}-0.098^{* * *} \\
(0.034)\end{array}$ & $\begin{array}{c}-0.115^{* * *} \\
(0.035)\end{array}$ & $\begin{array}{c}-0.116^{* * * *} \\
(0.035)\end{array}$ & $\begin{array}{c}-0.115^{* * * *} \\
(0.035)\end{array}$ \\
\hline Income & $\begin{array}{c}0.058^{* * * *} \\
(0.010)\end{array}$ & $\begin{array}{c}0.055^{* * * *} \\
(0.010)\end{array}$ & $\begin{array}{l}0.055^{* * * *} \\
(0.010)\end{array}$ & $\begin{array}{l}0.055^{* * * *} \\
(0.010)\end{array}$ \\
\hline Religion & $\begin{array}{c}-0.096^{* * * *} \\
(0.010)\end{array}$ & $\begin{array}{c}-0.097^{* * * *} \\
(0.010)\end{array}$ & $\begin{array}{c}-0.097^{* * * *} \\
(0.010)\end{array}$ & $\begin{array}{c}-0.097^{* * * *} \\
(0.010)\end{array}$ \\
\hline Ideological position & $\begin{array}{c}0.048^{* * *} \\
(0.005)\end{array}$ & $\begin{array}{l}0.041^{* * * *} \\
(0.006)\end{array}$ & $\begin{array}{l}0.041^{* * * *} \\
(0.006)\end{array}$ & $\begin{array}{l}0.041^{* * * *} \\
(0.006)\end{array}$ \\
\hline Economic evaluation & $\begin{array}{c}0.548^{* * * *} \\
(0.015)\end{array}$ & $\begin{array}{c}0.357^{* * * *} \\
(0.089)\end{array}$ & $\begin{array}{c}0.048 \\
(0.200)\end{array}$ & $\begin{array}{c}0.950^{* * * *} \\
(0.183)\end{array}$ \\
\hline Polarisation of alternatives & -0.004 & -0.006 & -0.006 & -0.009 \\
\hline Economy $\times$ polarisation & $(0.015)$ & $\begin{array}{l}(0.015) \\
0.021^{* *} \\
(0.008)\end{array}$ & $\begin{array}{l}(0.014) \\
0.023^{* *} \\
(0.008)\end{array}$ & $\begin{array}{l}(0.015) \\
0.017^{*} \\
(0.007)\end{array}$ \\
\hline Clarity of responsibility & & & -0.012 & \\
\hline Economy $\times$ clarity & & & $\begin{array}{c}(0.453) \\
0.503^{*} \\
(0.256)\end{array}$ & \\
\hline ENPP & & & & $\begin{array}{l}-0.101 \\
(0.091)\end{array}$ \\
\hline Economy $\times$ ENPP & & & & $\begin{array}{c}-0.144^{* * * *} \\
(0.041)\end{array}$ \\
\hline Constant & $\begin{array}{c}-0.520^{* *} \\
(0.175) \\
\end{array}$ & $\begin{array}{c}-0.487^{* *} \\
(0.174) \\
\end{array}$ & $\begin{array}{l}-0.415 \\
(0.348) \\
\end{array}$ & $\begin{array}{l}-0.067 \\
(0.413) \\
\end{array}$ \\
\hline $\begin{array}{l}N \text { (individuals) } \\
N \text { (groups) }\end{array}$ & $\begin{array}{c}29469 \\
32\end{array}$ & $\begin{array}{c}29469 \\
32\end{array}$ & $\begin{array}{c}29469 \\
32\end{array}$ & $\begin{array}{c}29469 \\
32\end{array}$ \\
\hline $\operatorname{Var}($ constant $)$ & $\begin{array}{c}0.408^{* * *} \\
(0.105)\end{array}$ & $\begin{array}{c}0.405^{* * *} \\
(0.104)\end{array}$ & $\begin{array}{c}0.352^{* * * *} \\
(0.085)\end{array}$ & $\begin{array}{c}0.389^{* * * *} \\
(0.100)\end{array}$ \\
\hline Var(evaluation) & & $\begin{array}{c}0.101^{\text {*** }} \\
(0.028)\end{array}$ & $\begin{array}{c}0.112^{* * * *} \\
(0.030)\end{array}$ & $\begin{array}{c}0.069^{* * *} \\
(0.020)\end{array}$ \\
\hline $\begin{array}{l}A I C \\
B I C\end{array}$ & $\begin{array}{l}35913.182 \\
36004.384\end{array}$ & $\begin{array}{l}35466.451 \\
35574.235\end{array}$ & $\begin{array}{l}35461.376 \\
35585.742\end{array}$ & $\begin{array}{l}35458.651 \\
35583.018\end{array}$ \\
\hline
\end{tabular}

Note: Entries are log-odds coefficients, standard errors reported in parentheses. Data: CSES module 1 and 4. Significance levels: ${ }^{*}: p<0.05 ;{ }^{* *}: p<0.01 ;{ }^{* * *}: p<0.001$. 
Dieter Stiers \& Ruth Dassonneville

Figure C.1: Average marginal effect of economic performance evaluations at different values of ideological polarisation between government and opposition

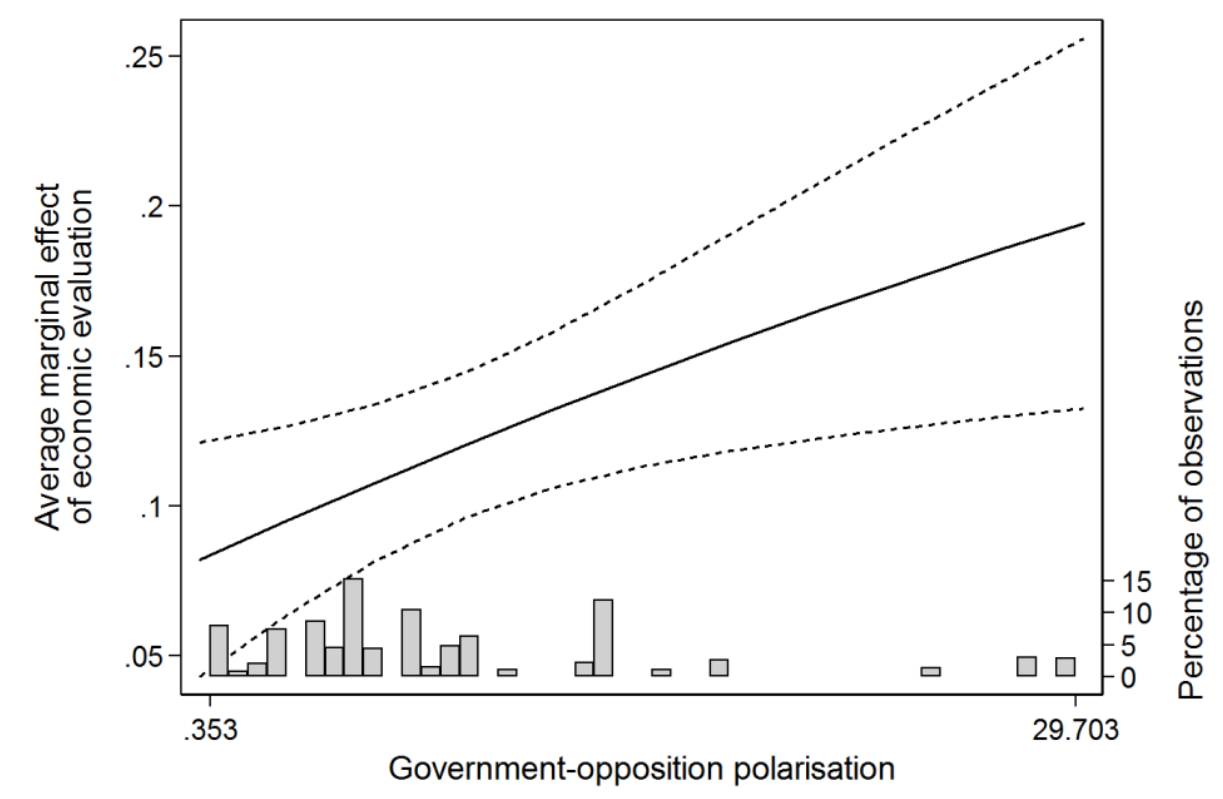

Note: the figure shows the average marginal effect and 95\% confidence intervals of retrospective economic performance evaluations based on Model 2 in Table C.1. Data: CSES 1, CSES 4. 
Dieter Stiers \& Ruth Dassonneville

\section{Appendix D: Results using individual perceptions of parties' positions}

Table D.1: Replication of Table 1 in the text using individual perceptions of parties' positions

\begin{tabular}{|c|c|c|c|c|}
\hline & $\begin{array}{c}(1) \\
\text { B } \\
\text { (s.e.) }\end{array}$ & $\begin{array}{l}(2) \\
\text { B } \\
\text { (s.e.) }\end{array}$ & $\begin{array}{l}(3) \\
\text { B } \\
\text { (s.e.) }\end{array}$ & $\begin{array}{l}(4) \\
\text { B } \\
\text { (s.e.) }\end{array}$ \\
\hline Sex (ref.=male) & $\begin{array}{c}0.036 \\
(0.025)\end{array}$ & $\begin{array}{c}0.037 \\
(0.025)\end{array}$ & $\begin{array}{c}0.032 \\
(0.026)\end{array}$ & $\begin{array}{c}0.037 \\
(0.025)\end{array}$ \\
\hline Age & $\begin{array}{c}0.009^{\text {**** }} \\
(0.001)\end{array}$ & $\begin{array}{c}0.010^{* * * *} \\
(0.001)\end{array}$ & $\begin{array}{c}0.010^{* * * *} \\
(0.001)\end{array}$ & $\begin{array}{c}0.010^{* * * *} \\
(0.001)\end{array}$ \\
\hline Education (ref.=no secondary & & & & \\
\hline Education: secondary & $\begin{array}{c}0.010 \\
(0.036)\end{array}$ & $\begin{array}{c}0.012 \\
(0.036)\end{array}$ & $\begin{array}{l}-0.087^{*} \\
(0.038)\end{array}$ & $\begin{array}{c}0.012 \\
(0.036)\end{array}$ \\
\hline Education: post-secondary & $\begin{array}{c}0.013 \\
(0.041)\end{array}$ & $\begin{array}{c}0.014 \\
(0.041)\end{array}$ & $\begin{array}{l}-0.039 \\
(0.042)\end{array}$ & $\begin{array}{c}0.014 \\
(0.041)\end{array}$ \\
\hline Education: university & $\begin{array}{l}-0.013 \\
(0.038)\end{array}$ & $\begin{array}{l}-0.011 \\
(0.038)\end{array}$ & $\begin{array}{l}-0.080^{*} \\
(0.039)\end{array}$ & $\begin{array}{l}-0.008 \\
(0.038)\end{array}$ \\
\hline Income & $\begin{array}{c}0.093^{* * *} \\
(0.010)\end{array}$ & $\begin{array}{c}0.093^{* * * *} \\
(0.010)\end{array}$ & $\begin{array}{c}0.082^{* * * *} \\
(0.010)\end{array}$ & $\begin{array}{c}0.093^{* * *} \\
(0.010)\end{array}$ \\
\hline Religion & $\begin{array}{c}0.023 \\
(0.012)\end{array}$ & $\begin{array}{c}0.022 \\
(0.012)\end{array}$ & $\begin{array}{c}0.022 \\
(0.012)\end{array}$ & $\begin{array}{c}0.021 \\
(0.012)\end{array}$ \\
\hline Ideological position & $\begin{array}{c}0.047^{* * *} \\
(0.005)\end{array}$ & $\begin{array}{c}0.045^{* * *} \\
(0.005)\end{array}$ & $\begin{array}{c}0.058^{* * * *} \\
(0.006)\end{array}$ & $\begin{array}{c}0.044^{* * * *} \\
(0.005)\end{array}$ \\
\hline Performance evaluation & $\begin{array}{l}1.302^{* * *} \\
(0.020)\end{array}$ & $\begin{array}{c}1.141^{* * *} \\
(0.029)\end{array}$ & $\begin{array}{l}1.014^{* * *} \\
(0.063)\end{array}$ & $\begin{array}{c}1.457^{* * * *} \\
(0.073)\end{array}$ \\
\hline Polarisation of alternatives & $\begin{array}{c}0.005^{* * *} \\
(0.001)\end{array}$ & $\begin{array}{c}0.004^{* * * *} \\
(0.001)\end{array}$ & $\begin{array}{c}0.004^{* * * *} \\
(0.001)\end{array}$ & $\begin{array}{c}0.004^{* * * *} \\
(0.001)\end{array}$ \\
\hline Evaluation $\times$ polarisation & & $\begin{array}{c}0.008^{* * *} \\
(0.001)\end{array}$ & $\begin{array}{c}0.010^{* * * *} \\
(0.001)\end{array}$ & $\begin{array}{c}0.006^{\text {**** }} \\
(0.001)\end{array}$ \\
\hline Clarity of responsibility & & & $\begin{array}{c}-1.266^{* *} \\
(0.401)\end{array}$ & \\
\hline Evaluation $\times$ clarity & & & $\begin{array}{c}0.479^{* * * *} \\
(0.094)\end{array}$ & \\
\hline ENPP & & & & $\begin{array}{c}0.130 \\
(0.090)\end{array}$ \\
\hline Evaluation $\times$ ENPP & & & & $\begin{array}{c}-0.080^{* * * *} \\
(0.017)\end{array}$ \\
\hline Constant & $\begin{array}{c}-0.748^{* * * *} \\
(0.114)\end{array}$ & $\begin{array}{c}-0.724^{* * *} \\
(0.114)\end{array}$ & $\begin{array}{c}0.098 \\
(0.271)\end{array}$ & $\begin{array}{c}-1.213^{* * * *} \\
(0.352)\end{array}$ \\
\hline$N$ (individuals) & 35892 & 35892 & 33920 & 35892 \\
\hline$N$ (groups) & 52 & 52 & 50 & 52 \\
\hline $\operatorname{Var}($ constant $)$ & $\begin{array}{c}0.624^{* * *} \\
(0.127)\end{array}$ & $\begin{array}{c}0.622^{* * *} \\
(0.126)\end{array}$ & $\begin{array}{c}0.541^{* * *} \\
(0.113)\end{array}$ & $\begin{array}{c}0.596^{* * *} \\
(0.121)\end{array}$ \\
\hline$A I C$ & 39863.616 & 39810.027 & 36653.576 & 39790.280 \\
\hline$B I C$ & 39965.475 & 39920.374 & 36780.052 & 39917.604 \\
\hline
\end{tabular}

Note: Entries are log-odds coefficients, standard errors reported in parentheses. Data: CSES Module 2 and 3. Significance levels: ${ }^{*}: p<0.05 ;{ }^{* *}: p<0.01 ;{ }^{* * *}: p<0.001$. 
Dieter Stiers \& Ruth Dassonneville

Figure D.1: Average marginal effect of performance evaluations at different values of ideological polarisation between government and opposition

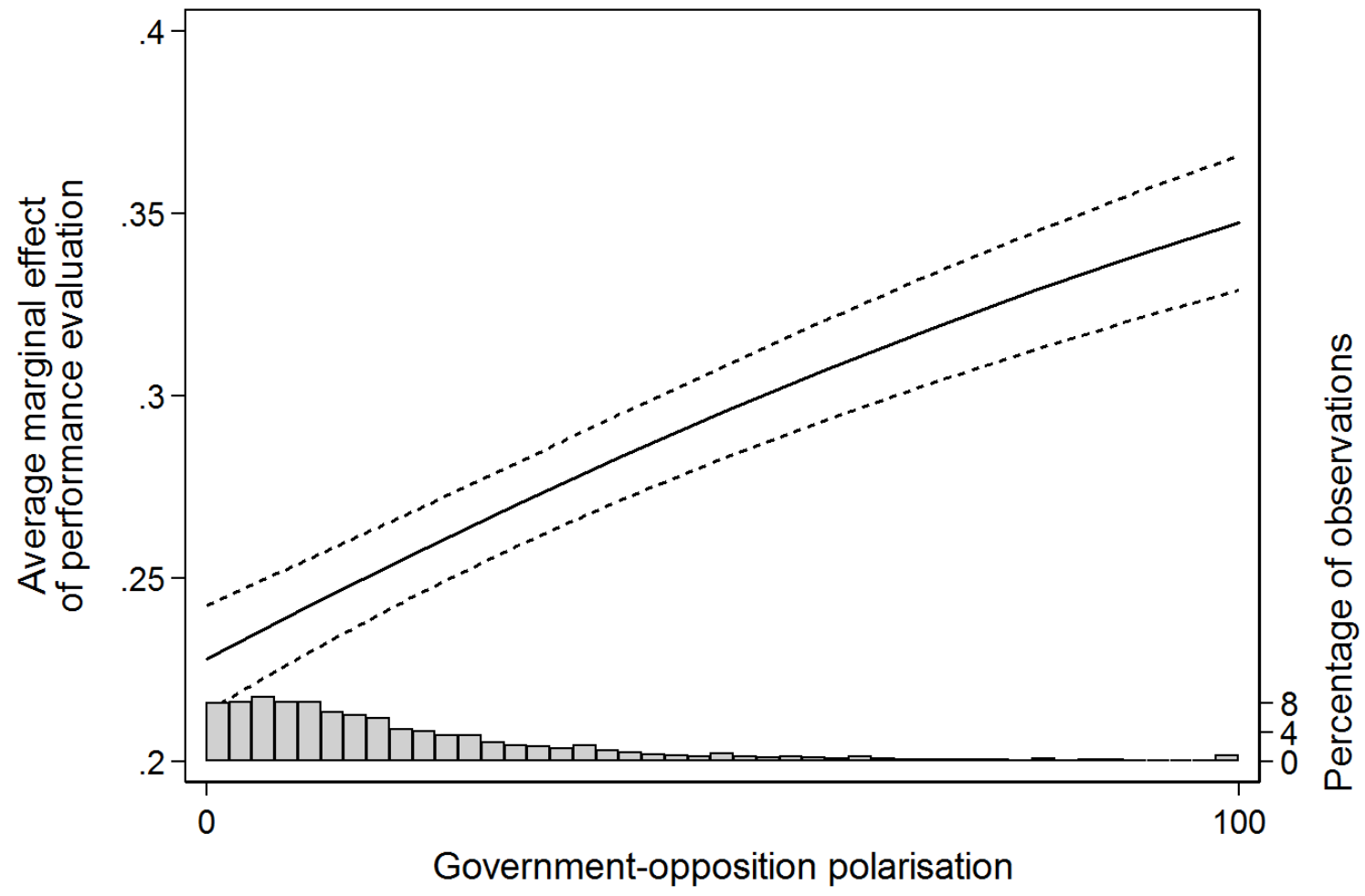

Note: the figure shows the average marginal effect and 95\% confidence intervals of retrospective performance evaluations based on Model 2 in Table D.1. Data: CSES 2, CSES 3. 
Dieter Stiers \& Ruth Dassonneville

\section{Appendix E: Results using only government cohesion as measure of clarity}

Table E.1: Replication of Table 1 in the text with cohesion as indicator of clarity

\begin{tabular}{|c|c|c|c|c|}
\hline & $\begin{array}{c}(1) \\
\text { B } \\
\text { (s.e.) }\end{array}$ & $\begin{array}{l}(2) \\
\text { B } \\
\text { (s.e.) }\end{array}$ & $\begin{array}{l}(3) \\
\text { B } \\
\text { (s.e.) }\end{array}$ & $\begin{array}{l}\text { (4) } \\
\text { B } \\
\text { (s.e.) }\end{array}$ \\
\hline Sex (ref.=male) & $\begin{array}{c}0.023 \\
(0.022)\end{array}$ & $\begin{array}{c}0.029 \\
(0.023)\end{array}$ & $\begin{array}{c}0.030 \\
(0.023)\end{array}$ & $\begin{array}{c}0.030 \\
(0.023)\end{array}$ \\
\hline Age & $\begin{array}{c}0.009^{* * *} \\
(0.001)\end{array}$ & $\begin{array}{c}0.010^{* * *} \\
(0.001)\end{array}$ & $\begin{array}{c}0.010^{* * *} \\
(0.001)\end{array}$ & $\begin{array}{c}0.010^{* * *} \\
(0.001)\end{array}$ \\
\hline Education (ref.=no secondar & & & & \\
\hline Education: secondary & $\begin{array}{l}-0.026 \\
(0.032)\end{array}$ & $\begin{array}{l}-0.053 \\
(0.033)\end{array}$ & $\begin{array}{c}-0.054 \\
(0.033)\end{array}$ & $\begin{array}{l}-0.054 \\
(0.033)\end{array}$ \\
\hline Education: post-secondary & $\begin{array}{l}-0.034 \\
(0.036)\end{array}$ & $\begin{array}{l}-0.041 \\
(0.037)\end{array}$ & $\begin{array}{l}-0.041 \\
(0.037)\end{array}$ & $\begin{array}{l}-0.041 \\
(0.037)\end{array}$ \\
\hline Education: university & $\begin{array}{l}-0.002 \\
(0.034)\end{array}$ & $\begin{array}{l}-0.006 \\
(0.036)\end{array}$ & $\begin{array}{l}-0.006 \\
(0.036)\end{array}$ & $\begin{array}{l}-0.006 \\
(0.036)\end{array}$ \\
\hline Income & $\begin{array}{c}0.088^{* * * *} \\
(0.009)\end{array}$ & $\begin{array}{c}0.084^{* * *} \\
(0.009)\end{array}$ & $\begin{array}{c}0.084^{* * *} \\
(0.009)\end{array}$ & $\begin{array}{c}0.084^{* * *} \\
(0.009)\end{array}$ \\
\hline Religion & $\begin{array}{c}0.026^{*} \\
(0.010)\end{array}$ & $\begin{array}{l}0.031^{* *} \\
(0.011)\end{array}$ & $\begin{array}{l}0.031^{* * *} \\
(0.011)\end{array}$ & $\begin{array}{l}0.031^{* *} \\
(0.011)\end{array}$ \\
\hline Ideological position & $\begin{array}{c}0.044^{* * * *} \\
(0.005)\end{array}$ & $\begin{array}{c}0.059^{* * *} \\
(0.005)\end{array}$ & $\begin{array}{c}0.059^{* * *} \\
(0.005)\end{array}$ & $\begin{array}{c}0.059^{* * *} \\
(0.005)\end{array}$ \\
\hline Performance evaluation & $\begin{array}{l}1.294^{* * * *} \\
(0.018)\end{array}$ & $\begin{array}{c}0.989^{* * * *} \\
(0.207)\end{array}$ & $\begin{array}{l}-0.093 \\
(0.547)\end{array}$ & $\begin{array}{l}1.830^{* * * *} \\
(0.419)\end{array}$ \\
\hline Polarisation of alternatives & $\begin{array}{l}-0.025 \\
(0.015)\end{array}$ & $\begin{array}{l}-0.035^{*} \\
(0.015)\end{array}$ & $\begin{array}{l}-0.028 \\
(0.015)\end{array}$ & $\begin{array}{l}-0.032^{*} \\
(0.015)\end{array}$ \\
\hline Evaluation $\times$ polarisation & & $\begin{array}{l}0.051^{* *} \\
(0.016)\end{array}$ & $\begin{array}{l}0.044^{* *} \\
(0.016)\end{array}$ & $\begin{array}{l}0.044^{* *} \\
(0.016)\end{array}$ \\
\hline Government cohesion & & & $\begin{array}{l}-1.324^{*} \\
(0.555)\end{array}$ & \\
\hline Evaluation $\times$ cohesion & & & $\begin{array}{l}1.279^{*} \\
(0.602)\end{array}$ & \\
\hline ENPP & & & & $\begin{array}{c}0.086 \\
(0.088)\end{array}$ \\
\hline Evaluation $\times$ ENPP & & & & $\begin{array}{l}-0.205^{*} \\
(0.090)\end{array}$ \\
\hline Constant & $\begin{array}{c}-0.339 \\
(0.199)\end{array}$ & $\begin{array}{l}-0.290 \\
(0.195)\end{array}$ & $\begin{array}{c}0.831 \\
(0.506)\end{array}$ & $\begin{array}{l}-0.640 \\
(0.408)\end{array}$ \\
\hline$N$ (individuals) & 45012 & 45012 & 45012 & 45012 \\
\hline$N$ (groups) & 52 & 52 & 52 & 52 \\
\hline $\operatorname{Var}($ constant $)$ & $\begin{array}{c}0.581^{\text {***** }} \\
(0.117)\end{array}$ & $\begin{array}{c}0.555^{* * *} \\
(0.113)\end{array}$ & $\begin{array}{c}0.500^{* * * *} \\
(0.102)\end{array}$ & $\begin{array}{c}0.545^{* * *} \\
(0.111)\end{array}$ \\
\hline Var(evaluation) & & $\begin{array}{c}0.619^{* * * *} \\
(0.127)\end{array}$ & $\begin{array}{c}0.567^{* * * *} \\
(0.117)\end{array}$ & $\begin{array}{c}0.562^{* * * *} \\
(0.115)\end{array}$ \\
\hline$\overline{A I C}$ & 50229.280 & 47739.479 & 47733.806 & 47737.621 \\
\hline$B I C$ & 50333.856 & 47861.485 & 47873.241 & 47877.056 \\
\hline
\end{tabular}


Dieter Stiers \& Ruth Dassonneville

\section{Appendix F: Results using adjusted control variables}

Table F.1: Replication of Table 1 in the text with adjusted control variables

\begin{tabular}{|c|c|c|c|c|}
\hline & $\begin{array}{c}(1) \\
\text { B } \\
\text { (s.e.) }\end{array}$ & $\begin{array}{l}\text { (2) } \\
\text { B } \\
\text { (s.e.) }\end{array}$ & $\begin{array}{l}(3) \\
\text { B } \\
\text { (s.e.) }\end{array}$ & $\begin{array}{l}\text { (4) } \\
\text { B } \\
\text { (s.e.) }\end{array}$ \\
\hline Sex (ref.=male) & $\begin{array}{l}-0.001 \\
(0.022)\end{array}$ & $\begin{array}{c}0.001 \\
(0.023)\end{array}$ & $\begin{array}{c}-0.001 \\
(0.024)\end{array}$ & $\begin{array}{c}0.001 \\
(0.023)\end{array}$ \\
\hline Age & $\begin{array}{c}0.003^{* * * *} \\
(0.001)\end{array}$ & $\begin{array}{c}0.004^{* * * *} \\
(0.001)\end{array}$ & $\begin{array}{c}0.003^{* * * *} \\
(0.001)\end{array}$ & $\begin{array}{c}0.004^{* * *} \\
(0.001)\end{array}$ \\
\hline Education (ref.=no secondary & & & & \\
\hline Education: secondary & $\begin{array}{c}0.001 \\
(0.033)\end{array}$ & $\begin{array}{l}-0.023 \\
(0.034)\end{array}$ & $\begin{array}{l}-0.082^{*} \\
(0.035)\end{array}$ & $\begin{array}{l}-0.023 \\
(0.034)\end{array}$ \\
\hline Education: post-secondary & $\begin{array}{l}-0.021 \\
(0.036)\end{array}$ & $\begin{array}{l}-0.028 \\
(0.037)\end{array}$ & $\begin{array}{l}-0.061 \\
(0.038)\end{array}$ & $\begin{array}{l}-0.028 \\
(0.037)\end{array}$ \\
\hline Education: university & $\begin{array}{l}0.114^{* *} \\
(0.035)\end{array}$ & $\begin{array}{l}0.116^{* *} \\
(0.036)\end{array}$ & $\begin{array}{c}0.071 \\
(0.037)\end{array}$ & $\begin{array}{l}0.116^{* *} \\
(0.036)\end{array}$ \\
\hline Income & $\begin{array}{c}0.055^{* * * *} \\
(0.009)\end{array}$ & $\begin{array}{c}0.050^{* * * *} \\
(0.009)\end{array}$ & $\begin{array}{l}0.042^{* * * *} \\
(0.009)\end{array}$ & $\begin{array}{c}0.050^{* * * *} \\
(0.009)\end{array}$ \\
\hline Religion & $\begin{array}{c}0.039^{* * * *} \\
(0.011)\end{array}$ & $\begin{array}{c}0.044^{* * *} \\
(0.011)\end{array}$ & $\begin{array}{c}0.044^{* * * *} \\
(0.011)\end{array}$ & $\begin{array}{c}0.044^{* * *} \\
(0.011)\end{array}$ \\
\hline Ideological position & $\begin{array}{c}0.200^{* * *} \\
(0.005)\end{array}$ & $\begin{array}{c}0.202^{* * *} \\
(0.005)\end{array}$ & $\begin{array}{c}0.216^{* * *} \\
(0.006)\end{array}$ & $\begin{array}{c}0.202^{* * *} \\
(0.005)\end{array}$ \\
\hline Performance evaluation & $\begin{array}{l}1.196^{* * * *} \\
(0.018)\end{array}$ & $\begin{array}{c}0.970^{* * * *} \\
(0.199)\end{array}$ & $\begin{array}{c}0.639^{*} \\
(0.271)\end{array}$ & $\begin{array}{l}1.849^{* * * *} \\
(0.399)\end{array}$ \\
\hline Polarisation of alternatives & $\begin{array}{l}-0.026 \\
(0.016)\end{array}$ & $\begin{array}{l}-0.036^{*} \\
(0.016)\end{array}$ & $\begin{array}{l}-0.031^{*} \\
(0.015)\end{array}$ & $\begin{array}{l}-0.033^{*} \\
(0.016)\end{array}$ \\
\hline Evaluation $\times$ polarisation & & $\begin{array}{l}0.043^{* *} \\
(0.015)\end{array}$ & $\begin{array}{l}0.037^{* * *} \\
(0.013)\end{array}$ & $\begin{array}{c}0.035^{*} \\
(0.015)\end{array}$ \\
\hline Clarity of responsibility & & & $\begin{array}{c}-1.013^{* * *} \\
(0.389)\end{array}$ & \\
\hline Evaluation $\times$ clarity & & & $\begin{array}{c}0.734^{*} \\
(0.353)\end{array}$ & \\
\hline ENPP & & & & $\begin{array}{c}0.082 \\
(0.091)\end{array}$ \\
\hline Evaluation $\times$ ENPP & & & & $\begin{array}{l}-0.215^{*} \\
(0.086)\end{array}$ \\
\hline Constant & $\begin{array}{l}-0.366 \\
(0.205)\end{array}$ & $\begin{array}{l}-0.326 \\
(0.202)\end{array}$ & $\begin{array}{c}0.311 \\
(0.301)\end{array}$ & $\begin{array}{l}-0.662 \\
(0.423)\end{array}$ \\
\hline$N$ (individuals) & 45012 & 45012 & 42458 & 45012 \\
\hline$N$ (groups) & 52 & 52 & 50 & 52 \\
\hline $\operatorname{Var}($ constant $)$ & $\begin{array}{c}0.618^{* * *} \\
(0.124)\end{array}$ & $\begin{array}{c}0.595^{* * *} \\
(0.121)\end{array}$ & $\begin{array}{c}0.509^{* * * *} \\
(0.107)\end{array}$ & $\begin{array}{c}0.586^{* * *} \\
(0.119)\end{array}$ \\
\hline Var(evaluation) & & $\begin{array}{c}0.567^{* * *} \\
(0.116)\end{array}$ & $\begin{array}{c}0.396^{* * *} \\
(0.086)\end{array}$ & $\begin{array}{c}0.506^{* * * *} \\
(0.104)\end{array}$ \\
\hline$A I C$ & 48827.974 & 46544.132 & 44126.411 & 46541.414 \\
\hline$B I C$ & 48932.550 & 46666.137 & 44264.912 & 46680.849 \\
\hline
\end{tabular}

Note: Entries are log-odds coefficients, standard errors reported in parentheses. Data: CSES Module 2 and 3. Significance levels: ${ }^{*}: p<0.05 ;{ }^{* *}: p<0.01{ }^{* * *}: p<0.001$. 
Dieter Stiers \& Ruth Dassonneville

Figure F.1: Average marginal effect of performance evaluations at different values of ideological polarisation between government and opposition

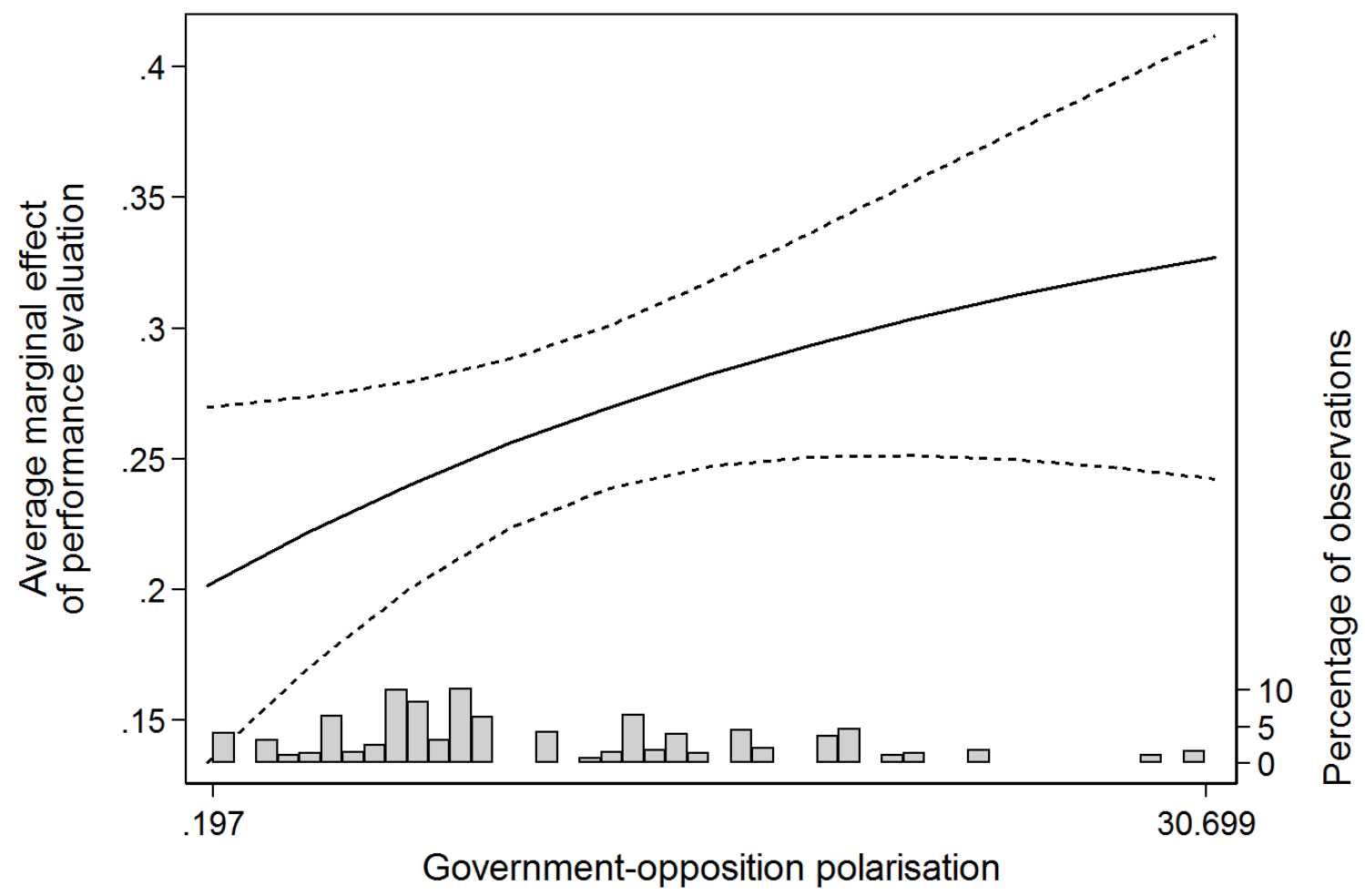

Note: the figure shows the average marginal effect and $95 \%$ confidence intervals of retrospective performance evaluations based on Model 2 in Table F.1. Data: CSES 2, CSES 3. 
Dieter Stiers \& Ruth Dassonneville

\section{Appendix G: Results for different knowledge-groups}

Table G.1: Replication of Table 1 in the text for the least knowledgeable respondents

\begin{tabular}{|c|c|c|c|c|}
\hline & $\begin{array}{c}(1) \\
\text { B } \\
\text { (s.e.) }\end{array}$ & $\begin{array}{l}(2) \\
\text { B } \\
\text { (s.e.) }\end{array}$ & $\begin{array}{l}(3) \\
\text { B } \\
\text { (s.e.) }\end{array}$ & $\begin{array}{l}\text { (4) } \\
\text { B } \\
\text { (s.e.) }\end{array}$ \\
\hline Sex (ref.=male) & $\begin{array}{c}0.074^{*} \\
(0.034)\end{array}$ & $\begin{array}{c}0.079^{*} \\
(0.035)\end{array}$ & $\begin{array}{c}0.086^{*} \\
(0.036)\end{array}$ & $\begin{array}{c}0.079^{*} \\
(0.035)\end{array}$ \\
\hline Age & $\begin{array}{c}0.009^{* * * *} \\
(0.001)\end{array}$ & $\begin{array}{c}0.010^{\text {**** }} \\
(0.001)\end{array}$ & $\begin{array}{c}0.010^{* * * *} \\
(0.001)\end{array}$ & $\begin{array}{c}0.010^{* * * *} \\
(0.001)\end{array}$ \\
\hline Education (ref.=no secondary & & & & \\
\hline Education: secondary & $\begin{array}{c}-0.072 \\
(0.050)\end{array}$ & $\begin{array}{l}-0.073 \\
(0.051)\end{array}$ & $\begin{array}{l}-0.105^{*} \\
(0.052)\end{array}$ & $\begin{array}{l}-0.075 \\
(0.051)\end{array}$ \\
\hline Education: post-secondary & $\begin{array}{l}-0.003 \\
(0.056)\end{array}$ & $\begin{array}{c}0.011 \\
(0.057)\end{array}$ & $\begin{array}{l}-0.006 \\
(0.058)\end{array}$ & $\begin{array}{c}0.009 \\
(0.057)\end{array}$ \\
\hline Education: university & $\begin{array}{l}-0.058 \\
(0.056)\end{array}$ & $\begin{array}{l}-0.051 \\
(0.058)\end{array}$ & $\begin{array}{c}-0.073 \\
(0.058)\end{array}$ & $\begin{array}{c}-0.052 \\
(0.058)\end{array}$ \\
\hline Income & $\begin{array}{c}0.076^{* * * *} \\
(0.013)\end{array}$ & $\begin{array}{c}0.072^{* * *} \\
(0.014)\end{array}$ & $\begin{array}{c}0.073^{* * *} \\
(0.014)\end{array}$ & $\begin{array}{c}0.072^{* * *} \\
(0.014)\end{array}$ \\
\hline Religion & $\begin{array}{c}0.036^{*} \\
(0.016)\end{array}$ & $\begin{array}{c}0.038^{*} \\
(0.016)\end{array}$ & $\begin{array}{c}0.038^{*} \\
(0.016)\end{array}$ & $\begin{array}{c}0.038^{*} \\
(0.016)\end{array}$ \\
\hline Ideological position & $\begin{array}{c}0.037^{* * * *} \\
(0.007)\end{array}$ & $\begin{array}{c}0.042^{* * *} \\
(0.008)\end{array}$ & $\begin{array}{c}0.048^{* * *} \\
(0.008)\end{array}$ & $\begin{array}{c}0.041^{* * *} \\
(0.008)\end{array}$ \\
\hline Performance evaluation & $\begin{array}{c}1.458^{* * * *} \\
(0.029)\end{array}$ & $\begin{array}{c}0.849^{* * *} \\
(0.206)\end{array}$ & $\begin{array}{c}0.490 \\
(0.295)\end{array}$ & $\begin{array}{c}1.680^{* * *} \\
(0.422)\end{array}$ \\
\hline Polarisation of alternatives & $\begin{array}{l}-0.021 \\
(0.016)\end{array}$ & $\begin{array}{l}-0.031^{*} \\
(0.015)\end{array}$ & $\begin{array}{l}-0.026 \\
(0.014)\end{array}$ & $\begin{array}{l}-0.028 \\
(0.015)\end{array}$ \\
\hline Evaluation $\times$ polarisation & & $\begin{array}{l}0.051^{* *} \\
(0.016)\end{array}$ & $\begin{array}{l}0.047^{* *} \\
(0.014)\end{array}$ & $\begin{array}{l}0.043^{* *} \\
(0.016)\end{array}$ \\
\hline Clarity of responsibility & & & $\begin{array}{l}-0.881^{*} \\
(0.362)\end{array}$ & \\
\hline Evaluation $\times$ clarity & & & $\begin{array}{c}0.746 \\
(0.382)\end{array}$ & \\
\hline ENPP & & & & $\begin{array}{c}0.077 \\
(0.087)\end{array}$ \\
\hline Evaluation $\times$ ENPP & & & & $\begin{array}{l}-0.203^{*} \\
(0.091)\end{array}$ \\
\hline Constant & $\begin{array}{l}-0.502^{*} \\
(0.213)\end{array}$ & $\begin{array}{l}-0.403^{*} \\
(0.193)\end{array}$ & $\begin{array}{c}0.145 \\
(0.282)\end{array}$ & $\begin{array}{l}-0.717 \\
(0.405)\end{array}$ \\
\hline$N$ (individuals) & 19772 & 19772 & 18889 & 19772 \\
\hline$N$ (groups) & 52 & 52 & 50 & 52 \\
\hline $\operatorname{Var}($ constant $)$ & $\begin{array}{c}0.647^{* * *} \\
(0.138)\end{array}$ & $\begin{array}{c}0.523^{* * *} \\
(0.113)\end{array}$ & $\begin{array}{c}0.423^{* * *} \\
(0.095)\end{array}$ & $\begin{array}{c}0.515^{* * * *} \\
(0.111)\end{array}$ \\
\hline Var(evaluation) & & $\begin{array}{c}0.580^{* * *} \\
(0.131) \\
\end{array}$ & $\begin{array}{c}0.431^{* * *} \\
(0.104) \\
\end{array}$ & $\begin{array}{c}0.528^{* * *} \\
(0.119) \\
\end{array}$ \\
\hline AIC & 21323.140 & 20697.465 & 20064.871 & 20695.942 \\
\hline$B I C$ & 21417.845 & 20807.954 & 20190.413 & 20822.214 \\
\hline
\end{tabular}

Note: Entries are log-odds coefficients, standard errors reported in parentheses. Data: CSES Module 2 and 3. Significance levels: ${ }^{*}: p<0.05 ;{ }^{* *}: p<0.01{ }^{* * *}: p<0.001$. 
Dieter Stiers \& Ruth Dassonneville

Figure G.1: Average marginal effect of performance evaluations at different values of ideological polarisation between government and opposition for the least knowledgeable respondents

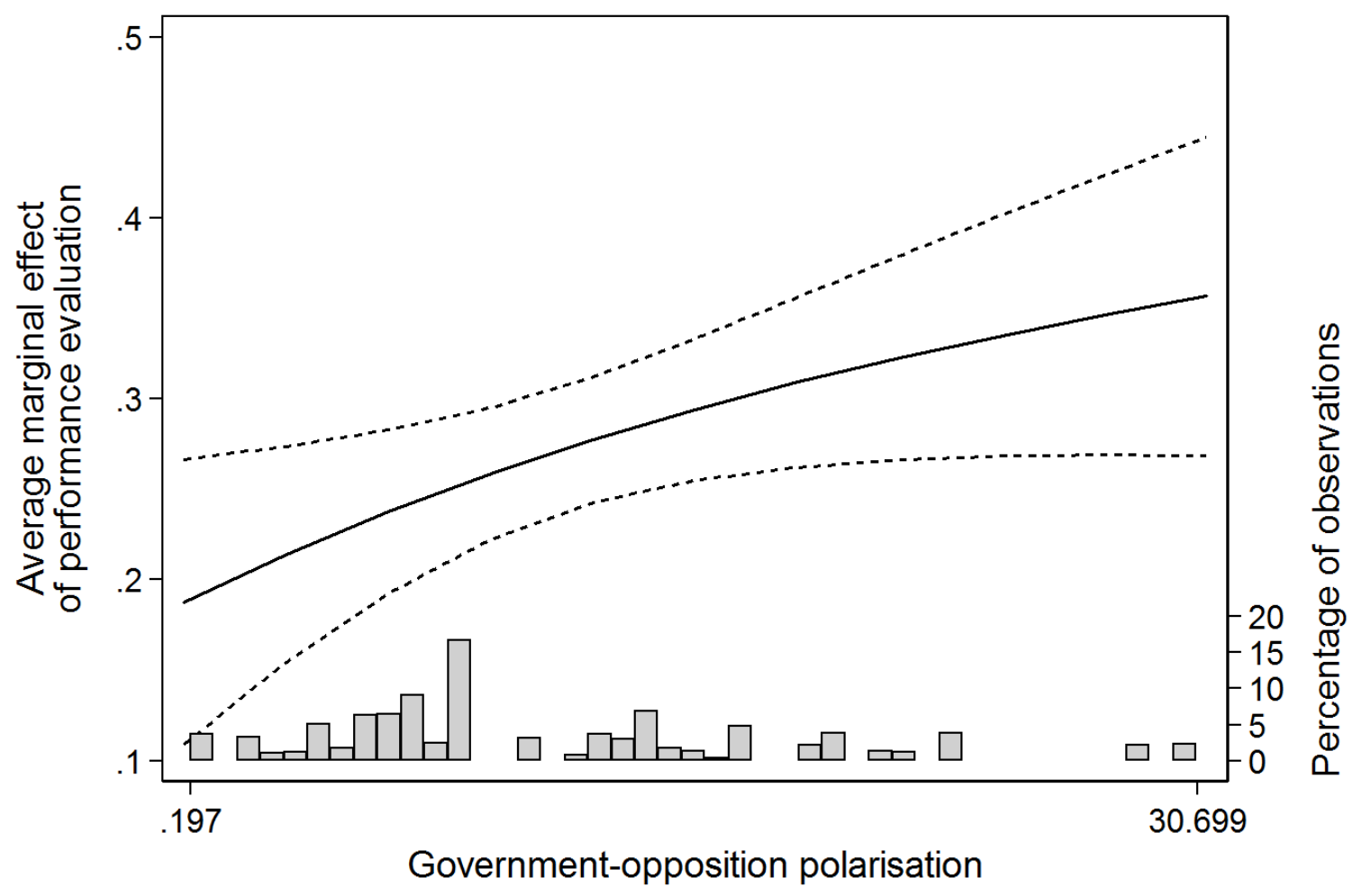

Note: the figure shows the average marginal effect and 95\% confidence intervals of retrospective performance evaluations based on Model 2 in Table G.1. Data: CSES 2, CSES 3. 
Dieter Stiers \& Ruth Dassonneville

Table G.2: Replication of Table 1 in the text for the most knowledgeable respondents

\begin{tabular}{|c|c|c|c|c|}
\hline & $\begin{array}{c}(1) \\
\text { B } \\
\text { (s.e.) }\end{array}$ & $\begin{array}{l}(2) \\
\text { B } \\
\text { (s.e.) }\end{array}$ & $\begin{array}{l}(3) \\
\text { B } \\
\text { (s.e.) }\end{array}$ & $\begin{array}{l}(4) \\
\text { B } \\
\text { (s.e.) }\end{array}$ \\
\hline Sex (ref.=male) & $\begin{array}{c}0.027 \\
(0.026)\end{array}$ & $\begin{array}{c}0.032 \\
(0.027)\end{array}$ & $\begin{array}{c}0.021 \\
(0.028)\end{array}$ & $\begin{array}{c}0.032 \\
(0.027)\end{array}$ \\
\hline Age & $\begin{array}{c}0.008^{* * * *} \\
(0.001)\end{array}$ & $\begin{array}{c}0.008^{* * * *} \\
(0.001)\end{array}$ & $\begin{array}{c}0.009^{* * * *} \\
(0.001)\end{array}$ & $\begin{array}{c}0.008^{* * *} \\
(0.001)\end{array}$ \\
\hline Education (ref.=no secondary & & & & \\
\hline Education: secondary & $\begin{array}{c}-0.078^{*} \\
(0.039)\end{array}$ & $\begin{array}{c}-0.111^{* *} \\
(0.041)\end{array}$ & $\begin{array}{c}-0.183^{* * * *} \\
(0.043)\end{array}$ & $\begin{array}{c}-0.112^{* *} \\
(0.041)\end{array}$ \\
\hline Education: post-secondary & $\begin{array}{c}-0.119^{* *} \\
(0.043)\end{array}$ & $\begin{array}{c}-0.123^{* *} \\
(0.045)\end{array}$ & $\begin{array}{c}-0.173^{* * * *} \\
(0.045)\end{array}$ & $\begin{array}{c}-0.124^{* *} \\
(0.045)\end{array}$ \\
\hline Education: university & $\begin{array}{l}-0.079 \\
(0.040)\end{array}$ & $\begin{array}{l}-0.092^{*} \\
(0.042)\end{array}$ & $\begin{array}{c}-0.151^{\text {***** }}(0.043)\end{array}$ & $\begin{array}{l}-0.092^{*} \\
(0.042)\end{array}$ \\
\hline Income & $\begin{array}{c}0.074^{* * * *} \\
(0.010)\end{array}$ & $\begin{array}{c}0.072^{* * *} \\
(0.011)\end{array}$ & $\begin{array}{c}0.063^{* * *} \\
(0.011)\end{array}$ & $\begin{array}{c}0.072^{* * *} \\
(0.011)\end{array}$ \\
\hline Religion & $\begin{array}{c}0.026^{*} \\
(0.012)\end{array}$ & $\begin{array}{c}0.031^{*} \\
(0.013)\end{array}$ & $\begin{array}{c}0.031^{*} \\
(0.013)\end{array}$ & $\begin{array}{c}0.031^{*} \\
(0.013)\end{array}$ \\
\hline Ideological position & $\begin{array}{c}0.055^{* * * *} \\
(0.006)\end{array}$ & $\begin{array}{c}0.072^{* * *} \\
(0.006)\end{array}$ & $\begin{array}{c}0.075^{* * *} \\
(0.007)\end{array}$ & $\begin{array}{c}0.072^{* * *} \\
(0.006)\end{array}$ \\
\hline Performance evaluation & $\begin{array}{c}1.326^{* * *} \\
(0.022)\end{array}$ & $\begin{array}{c}1.105^{* * *} \\
(0.225)\end{array}$ & $\begin{array}{c}0.806^{*} \\
(0.317)\end{array}$ & $\begin{array}{c}2.029^{* * *} \\
(0.455)\end{array}$ \\
\hline Polarisation of alternatives & $\begin{array}{l}-0.029 \\
(0.015)\end{array}$ & $\begin{array}{c}-0.039^{* *} \\
(0.015)\end{array}$ & $\begin{array}{l}-0.035^{*} \\
(0.014)\end{array}$ & $\begin{array}{l}-0.036^{*} \\
(0.015)\end{array}$ \\
\hline Evaluation $\times$ polarisation & & $\begin{array}{l}0.049^{* * *} \\
(0.018)\end{array}$ & $\begin{array}{l}0.044^{* *} \\
(0.016)\end{array}$ & $\begin{array}{c}0.041^{*} \\
(0.017)\end{array}$ \\
\hline Clarity of responsibility & & & $\begin{array}{l}-0.969^{*} \\
(0.378)\end{array}$ & \\
\hline Evaluation $\times$ clarity & & & $\begin{array}{c}0.691 \\
(0.414)\end{array}$ & \\
\hline ENPP & & & & $\begin{array}{c}0.090 \\
(0.087)\end{array}$ \\
\hline Evaluation $\times$ ENPP & & & & $\begin{array}{l}-0.226^{*} \\
(0.098)\end{array}$ \\
\hline Constant & $\begin{array}{l}-0.195 \\
(0.195)\end{array}$ & $\begin{array}{l}-0.168 \\
(0.194)\end{array}$ & $\begin{array}{c}0.461 \\
(0.292)\end{array}$ & $\begin{array}{l}-0.536 \\
(0.405)\end{array}$ \\
\hline$N$ (individuals) & 31289 & 31289 & 29613 & 31289 \\
\hline$N$ (groups) & 52 & 52 & 50 & 52 \\
\hline $\operatorname{Var}($ constant $)$ & $\begin{array}{c}0.550^{* * * *} \\
(0.112)\end{array}$ & $\begin{array}{c}0.542^{* * *} \\
(0.112)\end{array}$ & $\begin{array}{c}0.473^{* * *} \\
(0.100)\end{array}$ & $\begin{array}{c}0.531^{* * *} \\
(0.110)\end{array}$ \\
\hline Var(evaluation) & & $\begin{array}{c}0.718^{* * *} \\
(0.149) \\
\end{array}$ & $\begin{array}{c}0.540^{* * *} \\
(0.118) \\
\end{array}$ & $\begin{array}{c}0.650^{* * *} \\
(0.136) \\
\end{array}$ \\
\hline $\begin{array}{l}A I C \\
\text { BIC }\end{array}$ & $\begin{array}{l}35059.459 \\
35159.671\end{array}$ & $\begin{array}{l}33081.635 \\
33198.549\end{array}$ & $\begin{array}{l}31369.231 \\
31501.966\end{array}$ & $\begin{array}{l}33079.549 \\
33213.166\end{array}$ \\
\hline
\end{tabular}

Note: Entries are log-odds coefficients, standard errors reported in parentheses. Data: CSES Module 2 and 3. Significance levels: ${ }^{*}: p<0.05 ;{ }^{* *}: p<0.01{ }^{* * *}: p<0.001$. 
Dieter Stiers \& Ruth Dassonneville

Figure G.2: Average marginal effect of performance evaluations at different values of ideological polarisation between government and opposition for the most knowledgeable respondents

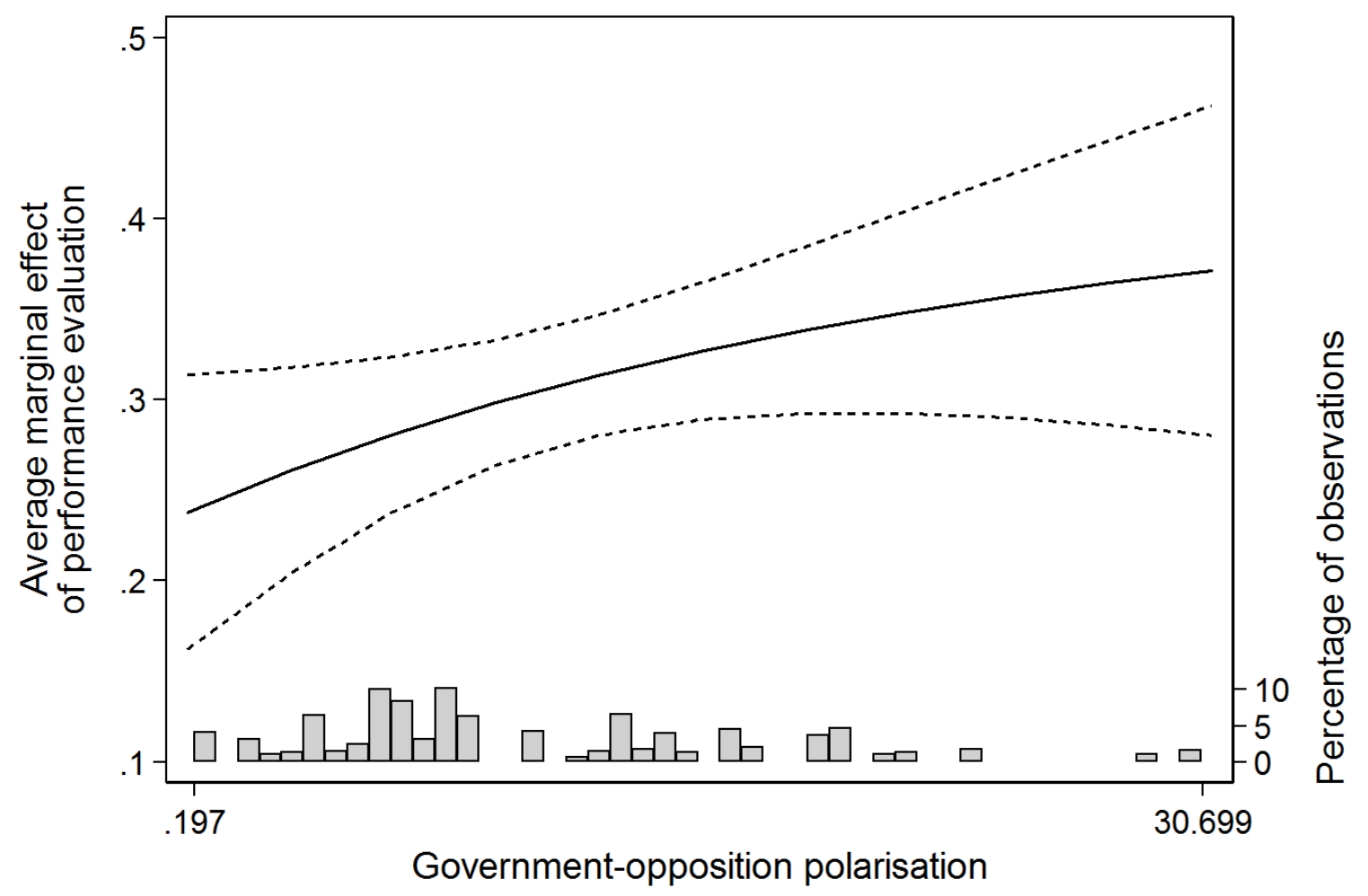

Note: the figure shows the average marginal effect and $95 \%$ confidence intervals of retrospective performance evaluations based on Model 2 in Table G.2. Data: CSES 2, CSES 3. 


\section{Appendix H: Controlling for endogeneity}

Following the design of Duch and Stevenson (2008, pp. 127-128) and Duch, Palmer, and Anderson (2000), we create purged performance evaluations based on a three-step approach. First, we predict performance evaluations by means of a model that includes variables that can be expected to biased evaluations as well as objective economic indicators (unemployment rate, inflation, GDP growth). Following Duch and colleagues, we focus on party identification with the incumbent, and political information as sources of bias. ${ }^{9}$ Second, we estimate the same model, but this time excluding the objective economic indicators. As a result, this model only includes the 'biased' part of performance evaluations (Evaluat By taking the difference of the two predictions, we obtain an estimate of performance evaluations based on actual economic conditions and purged from their endogeneity with the vote - and we label this variable Evaluation'. Hence, following Duch and Stevenson (2008, p. 128), we create the purged measure as follows:

$$
\begin{aligned}
& \text { Evaluation }_{i}=\alpha_{1}(P I D)+\alpha_{2}(\text { knowledge })+\alpha_{3}(\text { education })+\alpha_{4}(\text { unemployment }) \\
& +\alpha_{5}(\text { inflation })+\alpha_{6}(G D P)+\varepsilon_{i} \\
& \text { Evaluatıon }_{i}^{S}=\alpha_{1}(P I D)+\alpha_{2}(\text { knowledge })+\alpha_{3}(\text { education })+\varepsilon_{i} \\
& \text { Evaluatıon }_{i}^{\prime}=\text { Evaluation }_{i}-\text { Evaluat }{ }^{S}
\end{aligned}
$$

The purged variable is then included in the models as presented in the main text. The results of these models allow verifying whether our conclusions hold using exogenized evaluations of the government's performance. Note that, for this robustness test, we use standard OLS (first steps) and logit (presented) models, to allow the variation in objective economic indicators - which is at the election level - to have a varying effect on voters between countries.

\footnotetext{
${ }^{9}$ Note that Duch and Stevenson (2008) also include socio-economic status. However, as this variable was not included in some of the election studies, including it would lead to a substantial loss of observations.
} 
Dieter Stiers \& Ruth Dassonneville

Table H.1: Replication of Table 1 in the text using purged performance evaluations

\begin{tabular}{|c|c|c|c|c|}
\hline & $\begin{array}{c}(1) \\
\text { B } \\
\text { (s.e. }) \\
\end{array}$ & $\begin{array}{l}(2) \\
\text { B } \\
\text { (s.e.) }\end{array}$ & $\begin{array}{c}(3) \\
\text { B } \\
\text { (s.e.) }\end{array}$ & $\begin{array}{c}(4) \\
\text { B } \\
\text { (s.e.) }\end{array}$ \\
\hline Sex (ref.=male) & $\begin{array}{l}0.029 \\
(0.023)\end{array}$ & $\begin{array}{l}0.026 \\
(0.023)\end{array}$ & $\begin{array}{l}0.030 \\
(0.023)\end{array}$ & $\begin{array}{l}0.035 \\
(0.023)\end{array}$ \\
\hline Age & $\begin{array}{l}0.009^{* * *} \\
(0.001)\end{array}$ & $\begin{array}{l}0.009^{* * * *} \\
(0.001)\end{array}$ & $\begin{array}{l}0.008^{* * *} \\
(0.001)\end{array}$ & $\begin{array}{l}0.008^{* * * *} \\
(0.001)\end{array}$ \\
\hline \multicolumn{5}{|c|}{ Education (ref.=no secondary) } \\
\hline Education: secondary & $\begin{array}{l}0.087^{* *} \\
(0.030)\end{array}$ & $\begin{array}{l}0.093^{* *} \\
(0.030)\end{array}$ & $\begin{array}{l}0.051 \\
(0.031)\end{array}$ & $\begin{array}{l}0.016 \\
(0.031)\end{array}$ \\
\hline Education: post-secondary & $\begin{array}{l}0.085^{*} \\
(0.034)\end{array}$ & $\begin{array}{l}0.101^{* * *} \\
(0.034)\end{array}$ & $\begin{array}{l}0.054 \\
(0.035)\end{array}$ & $\begin{array}{l}0.036 \\
(0.035)\end{array}$ \\
\hline Education: university & $\begin{array}{l}0.027 \\
(0.033)\end{array}$ & $\begin{array}{l}0.029 \\
(0.033)\end{array}$ & $\begin{array}{l}0.022 \\
(0.034)\end{array}$ & $\begin{array}{l}-0.011 \\
(0.034)\end{array}$ \\
\hline Income & $\begin{array}{l}0.084^{* * * *} \\
(0.009)\end{array}$ & $\begin{array}{l}0.083^{* * * *} \\
(0.009)\end{array}$ & $\begin{array}{l}0.077^{* * * *} \\
(0.009)\end{array}$ & $\begin{array}{l}0.086^{* * *} \\
(0.009)\end{array}$ \\
\hline Religion & $\begin{array}{l}-0.004 \\
(0.009)\end{array}$ & $\begin{array}{l}0.018 \\
(0.010)\end{array}$ & $\begin{array}{l}0.019^{*} \\
(0.010)\end{array}$ & $\begin{array}{l}0.033^{* * *} \\
(0.010)\end{array}$ \\
\hline Ideological position & $\begin{array}{l}0.044^{* * *} \\
(0.005)\end{array}$ & $\begin{array}{l}0.044^{* * *} \\
(0.005)\end{array}$ & $\begin{array}{l}0.045^{* * * *} \\
(0.005)\end{array}$ & $\begin{array}{l}0.045^{* * *} \\
(0.005)\end{array}$ \\
\hline Performance evaluation' & $\begin{array}{l}0.599^{* * * *} \\
(0.073)\end{array}$ & $\begin{array}{l}-1.062^{* * * *} \\
(0.182)\end{array}$ & $\begin{array}{l}-3.356^{* * * *} \\
(0.270)\end{array}$ & $\begin{array}{l}-2.670^{* * * *} \\
(0.369)\end{array}$ \\
\hline Polarisation of alternatives & $\begin{array}{l}-0.016^{* * *} \\
(0.002)\end{array}$ & $\begin{array}{l}-0.013^{* * *} \\
(0.002)\end{array}$ & $\begin{array}{l}-0.012^{* * *} \\
(0.002)\end{array}$ & $\begin{array}{l}-0.009^{* * *} \\
(0.002)\end{array}$ \\
\hline Evaluation' $\times$ polarisation & & $\begin{array}{l}0.140^{* * * *} \\
(0.014)\end{array}$ & $\begin{array}{l}0.156^{* * * *} \\
(0.014)\end{array}$ & $\begin{array}{l}0.148^{* * * *} \\
(0.014)\end{array}$ \\
\hline Clarity of responsibility & & & $\begin{array}{l}1.123^{* * *} \\
0.049)\end{array}$ & \\
\hline Evaluation' $\times$ clarity & & & $\begin{array}{l}3.651^{\text {**** }} \\
(0.337)\end{array}$ & \\
\hline ENPP & & & & $\begin{array}{l}0.096^{* * *} \\
(0.011)\end{array}$ \\
\hline Evaluation' $\times$ ENPP & & & & $\begin{array}{l}0.418^{* * * *} \\
(0.083)\end{array}$ \\
\hline Constant & $\begin{array}{l}-1.171^{* * *} \\
(0.066)\end{array}$ & $\begin{array}{l}-1.218^{* * *} \\
(0.066)\end{array}$ & $\begin{array}{l}-0.500^{* * * *} \\
(0.074)\end{array}$ & $\begin{array}{l}-1.583^{* * *} \\
(0.082)\end{array}$ \\
\hline $\bar{N}$ & 32303 & 32303 & 32303 & 32303 \\
\hline Pseudo $R^{2}$ & 0.013 & 0.015 & 0.029 & 0.018 \\
\hline$A I C$ & 43182.611 & 43085.032 & 42491.305 & 42947.278 \\
\hline$B I C$ & 43274.823 & 43185.627 & 42608.665 & 43064.639 \\
\hline
\end{tabular}

Note: Entries are log-odds coefficients, standard errors reported in parentheses. Data: CSES Module 2 and 3. Significance levels: ${ }^{*}: p<0.05 ;{ }^{* *}: p<0.01 ;{ }^{* * *}: p<0.001$. 
Figure H.1: Replication of Figure 1 of the text using instrumented performance evaluations

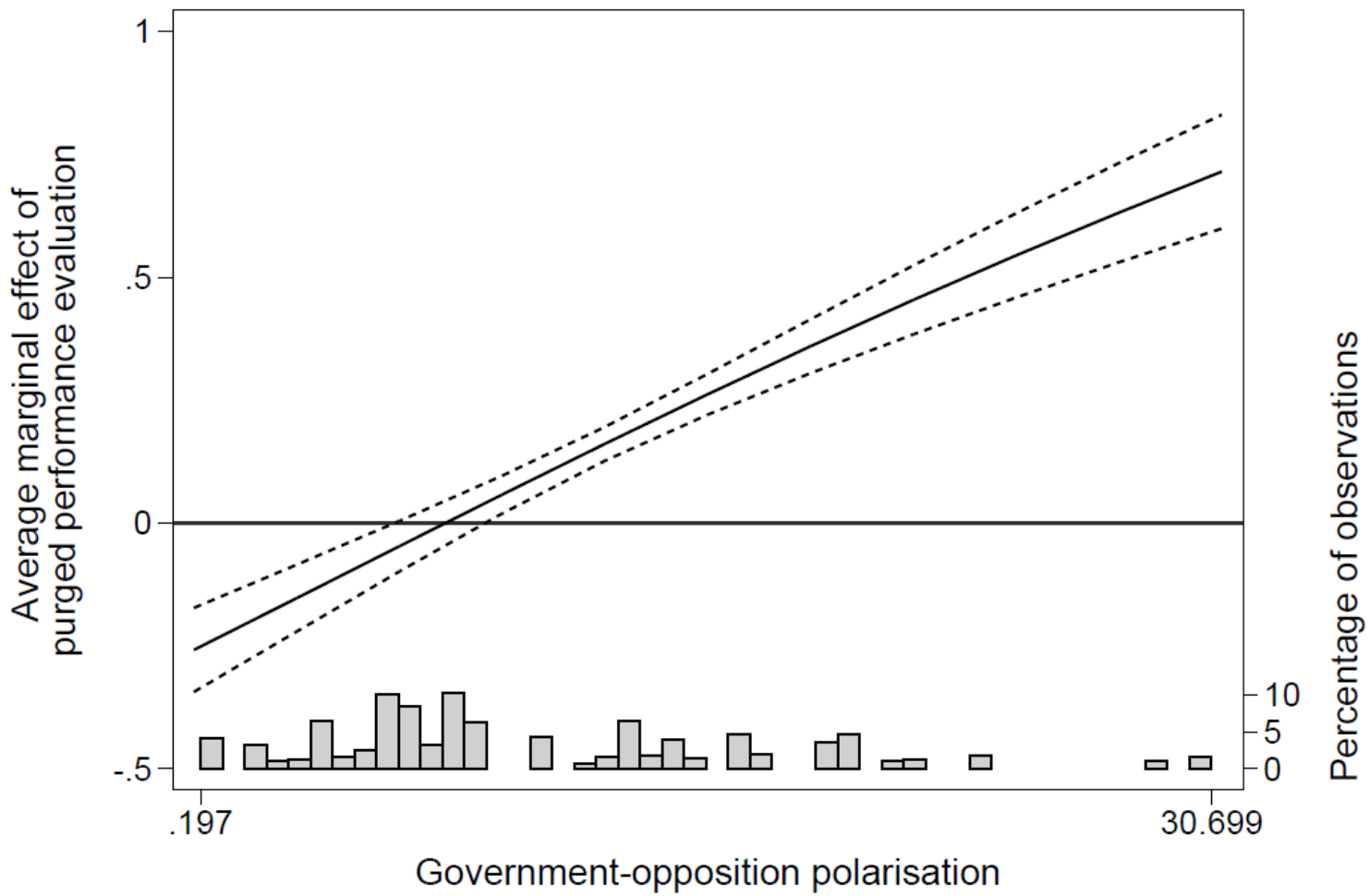

Note: the figure shows the average marginal effect and 95\% confidence intervals of retrospective performance evaluations based on Model 2 in Table H.1. Data: CSES 2, CSES 3.

As can be seen in Table H.1, the results from the models with purged performance evaluations are very comparable to those using the possibly endogenous evaluations. The replication of Figure 1 of the text shows that the substantial results are very similar as well. Surprisingly, the effect of performance evaluations on incumbent voting seems to be negative at the lowest values of polarisation of alternatives. However, this result is most likely due to the fact that our models can never fully account for all bias nor the full objective situation of a country, and hence the purged evaluations we use are an approximation of reality-based performance evaluations rather than a perfect measure. 